NBER WORKING PAPER SERIES

\title{
WHEN IT RAINS, IT POURS: PROCYCLICAL CAPITAL FLOWS AND MACROECONOMIC POLICIES
}

\author{
Graciela L. Kaminsky \\ Carmen M. Reinhart \\ Carlos A. Végh \\ Working Paper 10780 \\ http://www.nber.org/papers/w10780 \\ NATIONAL BUREAU OF ECONOMIC RESEARCH \\ 1050 Massachusetts Avenue \\ Cambridge, MA 02138 \\ September 2004
}

\begin{abstract}
Kaminsky was visiting the IMF Institute and Végh was Senior Resident Scholar at the IMF's Research Department when this paper was written. They both gratefully acknowledge the IMF's hospitality. Kaminsky and Végh also wish to thank the Institute of Public Policy at George Washington University and the UCLA Senate, respectively, for financial support. The authors wish to thank Peter Benczur, Mark Gertler, Gita Gopinath, Ayhan Kose, Pablo Lopez Murphy, Attila Raftai, Raghu Rajan, Alessandro Rebucci, Vincent R. Reinhart, Roberto Rigobon, Kenneth S. Rogoff, Evan Tanner, and Guillermo Tolosa for useful comments and suggestions and Eric Bang and, especially, Ioannis Tokatlidis for excellent research assistance. This paper was prepared for the NBER's 19th Conference on Macroeconomics, organized by Mark Gertler and Kenneth S. Rogoff. The views expressed herein are those of the author(s) and not necessarily those of the IMF or the National Bureau of Economic Research.

(C2004 by Graciela L. Kaminsky, Carmen M. Reinhart, and Carlos A. Végh. All rights reserved. Short sections of text, not to exceed two paragraphs, may be quoted without explicit permission provided that full credit, including (C) notice, is given to the source.
\end{abstract}


When it Rains, it Pours: Procyclical Capital Flows and Macroeconomic Policies

Graciela L. Kaminsky, Carmen M. Reinhart, and Carlos A. Végh

NBER Working Paper No. 10780

September 2004

JEL No. F41, E52, E62

\begin{abstract}
Based on a sample of 104 countries, we document four key stylized facts regarding the interaction between capital flows, fiscal policy, and monetary policy. First, net capital inflows are procyclical (i.e., external borrowing increases in good times and falls in bad times) in most OECD and developing countries. Second, fiscal policy is procyclical (i.e., government spending increases in good times and falls in bad times) for the majority of developing countries. Third, for emerging markets, monetary policy appears to be procyclical (i.e., policy rates are lowered in good times and raised in bad times). Fourth, in developing countries - and particularly for emerging markets periods of capital inflows are associated with expansionary macroeconomic policies and periods of capital outflows with contractionary macroeconomic policies. In such countries, therefore, when it rains, it does indeed pour.

Graciela L. Kaminsky

George Washington University

Department of Economics

Washington, DC 20052

and NBER

graciela@gwu.edu

Carmen M. Reinhart

School of Public Affairs and

Department of Economics

University of Maryland

4105 Van Munching Hall

College Park, MD 20742

and NBER

creinhar@umd.edu

Carlos A. Végh

Department of Economics

University of California, Los Angeles

Los Angeles, CA 90095-1477

and NBER

cvegh@ucla.edu
\end{abstract}




\section{INTRODUCTION}

Any expert on financial crises in emerging markets could cite ample anecdotal evidence to support the view that macroeconomic policies are highly procyclical, at least in moments of extreme duress. At the time that economic activity is contracting (often markedly) amidst a crisis, the fiscal authority cuts budgets deficits while the central bank raises interest rates - possibly exacerbating the economic contraction. Procyclical policies, however, do not appear to be limited to crisis periods in many developing countries. In fact, the roots of most of the debt crises in emerging market are all too often found in governments that go through bouts of high spending and borrowing when the times are favorable and international capital is plentiful. ${ }^{1}$

Gavin and Perotti (1997) first called attention to the phenomenon of procyclical fiscal policy by showing that fiscal policy in Latin America tends to be expansionary in good times and contractionary in bad times. Talvi and Végh (2000) argued that, far from being a phenomenon peculiar to Latin America, procyclical fiscal policy seems to be the norm in the developing world just as fiscal policy is acyclical in the advanced economies. Using a different econometric approach, Braun (2001) reaches a similar conclusion for developing countries, though he finds evidence that fiscal policy is countercyclical in OECD countries. Lane (2003b) also provides evidence on the procyclicality of fiscal policy in developing countries compared to OECD countries. In the same vein, Gupta et al (2004) find econometric support for the procyclicality of government spending in developing countries, though the degree of procyclicality varies across spending categories.

Several explanations have been advanced to explain the procyclicality of fiscal policy in developing countries compared to industrial countries. Gavin and Perotti (1997), among others, have argued that developing countries face credit constraints that prevent them from borrowing in bad times. Hence, they are "forced" to repay in bad times, which requires a contractionary fiscal policy. In contrast, Tornell and Lane (1999) develop a political-economy model in which competition for a common pool of

\footnotetext{
${ }^{1}$ See Reinhart, Rogoff, and Savastano (2003) for an analysis of borrowing/default cycles.
} 
funds among different units (ministries, provinces) leads to the so-called "voracity effect," whereby expenditure could actually exceed a given windfall. Taking as given such a political distortion, Talvi and Végh (2000) show how policymakers would find it optimal to run smaller primary surpluses in good times by increasing government spending and reducing tax rates. Lastly, Riascos and Végh (2003) show how incomplete markets could explain procyclical fiscal policy as the outcome of a Ramsey problem without having to impose any additional frictions.

In terms of monetary policy, while the impression certainly exists that developing countries often tighten the monetary strings in bad times (see Lane, 2003b), systematic empirical work is scant. ${ }^{2}$ This is probably due to the notorious difficulties (present even for advanced countries) in empirically characterizing the stance of monetary policy. ${ }^{3}$

Relying on data for 104 countries for the period 1960-2003, this paper revisits the evidence on the procyclicality of fiscal policy and, as far as we know, presents a first systematic effort to document empirically the cyclical properties of monetary policy in developing countries. It departs from earlier efforts investigating fiscal policy cycles in several dimensions. First, it provides an analytical framework for how to interpret the behavior of a broad variety of fiscal indicators, which leads to a reinterpretation of some earlier results in the literature. Second, it analyzes countries grouped by income levels to capture the fact that while wealthier countries have continuous access to international capital markets, lowincome countries are almost exclusively shut out at all times, and middle-income countries have a precarious and volatile relationship with international capital. Third, it examines closely the interaction

\footnotetext{
${ }^{2}$ Of course if "bad times" are defined exclusively as currency or banking crises, then there is a small but growing theoretical literature on monetary policy in general and interest rate defenses in particular (see, for instance, Aghion, Bacchetta, and Banerjee (2001), Flood and Jeanne (2000), and Lahiri and Végh (2003)). The empirical evidence in this area is, however, rather inconclusive.

${ }^{3}$ For a discussion of some of the challenges in estimating monetary policy rules for industrial countries, see Clarida, Gali, and Gertler (1999).
} 
between the business cycle, international capital flows, and macroeconomic policy. ${ }^{4}$ Our premise is that the capital flow cycle is tied to the business cycle and may even influence macroeconomic policies, particularly in middle income countries. Fourth, it offers an eclectic approach toward defining "good" and "bad" times and measuring the stance of fiscal and monetary policy by employing a broad range of indicators. Fifth, it disaggregates the sample along a variety of dimensions, by (i) differentiating crises episodes from tranquil periods, (ii) treating the more rigid exchange rate arrangements separately from the more flexible ones, and (iii) comparing earlier and more recent periods to assess whether the degree of capital market integration has altered cyclical patterns and relationships. Lastly, the analysis offers more comprehensive country coverage than earlier efforts.

The paper proceeds as follows. The next section discusses the underlying conceptual framework used to interpret the data on capital flows and fiscal and monetary policy and describes the approach followed to define business cycles. Section III presents a broad brush view of our main findings while Section IV provides greater detail on the main stylized facts by grouping countries according to income per capita levels, type of exchange rate arrangement, and other relevant subsamples. Section V contains concluding remarks.

\section{CONCEPTUAL FRAMEWORK}

This section lays out the conceptual framework used to interpret our empirical findings in the following sections. Specifically, we will discuss how to think about the cyclical properties of capital flows, fiscal policy, and monetary policy. A thorough reading of the blossoming literature in the area of policy cyclicality in developing countries reveals a somewhat loose approach to defining basic concepts, which often renders the discussion rather imprecise. For instance, countercyclical fiscal policy is often defined as running fiscal deficits in bad times and surpluses in good times (i.e., as a positive correlation

\footnotetext{
${ }^{4}$ Throughout this paper, "business cycle" refers to the real GDP cycle.
} 
between changes in output and changes in the fiscal balance). As we will argue, however, this is an unfortunate way of defining the concept since running a fiscal deficit in bad times may be consistent with rather different approaches to fiscal stabilization. In the same vein, considering fiscal variables as a proportion of GDP - as is most often done in this literature - could yield misleading results since the cyclical stance of fiscal policy may be dominated by the cyclical behavior of output.

In light of these critical conceptual issues - and at the risk of perhaps appearing sometimes obvious - we will be very specific as to how we define countercyclicality, procyclicality, and acyclicality.

\section{II.1 Capital flows}

We define the cyclical properties of capital flows as follows (Table 1):

Table 1

Capital Flows: Theoretical Correlations with the Business Cycle

\begin{tabular}{|lcc|}
\hline & Net Capital Inflows & $\begin{array}{c}\text { Net Capital } \\
\text { Inflows/GDP }\end{array}$ \\
\hline Countercyclical & - & - \\
Procyclical & + & $+/ 0 /-$ \\
Acyclical & 0 & - \\
\hline
\end{tabular}

i. Capital flows into a country are said to be countercyclical when the correlation between the cyclical components of net capital inflows and output is negative. In other words, the economy borrows from abroad in bad times (i.e., capital flows in) and lends/repays in good times (i.e., capital flows out).

ii. Capital flows are procyclical when the correlation between the cyclical components of net capital inflows and output is positive. The economy thus borrows from abroad in good times (i.e., capital flows in) and lends/repays in bad times (i.e., capital flows out).

iii. Capital flows are acyclical when the correlation between the cyclical components of net capital inflows and output is not statistically significant. The pattern of international borrowing and lending is thus not systematically related to the business cycle. 
While this may appear self evident, the mapping between the cyclical properties of net capital inflows as a share of GDP (a commonly used measure) and the business cycle is not clear cut. As the third column of Table 1 indicates, in the case of countercyclical capital inflows, this ratio should also have a negative correlation with output since in good (bad) times, net capital inflows fall (increase) and GDP increases (fall). In the case of procyclical net capital inflows, however, this ratio could have any sign since in good (bad) times, net capital inflows increase (fall) and GDP also increases (falls). In the acyclical case, the behavior of the ratio is dominated by the changes in GDP and therefore has a negative correlation. Thus, the ratio of net capital inflows to GDP will only provide an unambiguous indication of the cyclicality of net capital inflows if it has a positive sign (or is zero) in which case it would be indicating procylical capital flows. However, if it has a negative sign, it does not allow us to discriminate among the three cyclical patterns.

Our definition of the cyclical properties of capital flows thus focuses on whether capital flows tend to reinforce or "stabilize" the business cycle. To fix ideas, consider the standard endowment model of a small open economy (with no money). In the absence of any intertemporal distortion, households would want to keep consumption flat over time. Thus, in response to a temporary negative endowment shock, the economy would borrow from abroad to sustain the permanent level of consumption. During good times, the economy would repay its debt. Saving is thus positively correlated with the business cycle. Hence, in the standard model with no investment, capital inflows would be countercyclical and would tend to stabilize the cycle. Naturally, the counterpart of countercyclical borrowing in the standard real model is a procyclical current account.

Conversely, if the economy borrowed during good times and lent during bad times, capital flows would be procyclical as they would tend to reinforce the business cycle. In this case, the counterpart would be a countercyclical current account. Plausible theoretical explanations for procyclical capital flows include the following. First, suppose that physical capital is added to the basic model described above and that the business cycle is driven by productivity shocks. Then, a temporary and positive productivity shock would lead to an increase in saving (for the consumption smoothing motives described 
above) and to an increase in investment (as the return on capital has increased). If the investment effect dominates, then borrowing would be procyclical as the need to finance profitable investment more than offsets the saving effect.

A second explanation - particularly relevant for emerging countries - would result from intertemporal distortions in consumption imposed by temporary policies (like inflation stabilization programs or temporary liberalization policies; see Calvo, 1987, and Calvo and Végh, 1999). An unintended consequence of such temporary policies is to make consumption relatively cheaper during good times (by reducing the effective price of consumption), thus leading to a consumption boom which is financed by borrowing from abroad. In this case, saving falls in good times which renders capital flows procyclical. $^{5}$

A third possibility - also relevant for emerging countries - is that the availability of international capital varies with the business cycle. If foreign investors respond to the evidence of an improving local economy by bidding down country risk premiums (perhaps encouraged by low interest rates at financial centers), residents of the small economy may view this as a temporary opportunity to finance consumption cheaply and, therefore, dissave. ${ }^{6}$ We should remember that the consumption booms financed by capital inflows in many emerging market economies in the first part of the 1990 s were seen at the time as an example of the "capital inflow problem," as in Calvo, Leiderman, and Reinhart (1993, 1994).

Finally, notice that, in practice, movements in international reserves could break the link between procyclical borrowing and current account deficits (or countercyclical borrowing and current account surpluses) that would arise in the basic real intertemporal model. Indeed, recall the basic balance of payments accounting identity:

\footnotetext{
${ }^{5}$ Lane and Tornell (1998) offer some empirical evidence that shows that saving in Latin American countries has often been countercyclical (i.e., saving falls in good times and vice versa).

${ }^{6}$ Section IV presents evidence in support of this hypothesis. See also Neumeyer and Perri (2004) who examine the importance of country risk in driving the business cycle in emerging economies.
} 


\section{Change in international reserves $=$ Current account balance + capital account balance .}

Hence, say, positive net capital inflows (a capital account surplus) would not necessarily be associated with a negative current account balance if international reserves were increasing. Therefore, the cyclical properties of the current account are an imperfect indicator of those of capital flows.

\section{II.2 Fiscal policy}

Since the concept of policy cyclicality is important to the extent that it can help us understand or guide actual policy, it only makes sense to define policy cyclicality in terms of policy instruments, as opposed to outcomes (i.e., endogenous variables). Hence, we will define the cyclicality of fiscal policy in terms of government spending $(\mathrm{g})$ and tax rates $(\tau)$ (instead of defining it in terms of, say, the fiscal balance or tax revenues). Given this definition, we will then examine the cyclical implications for important endogenous variables such as the primary fiscal balance, tax revenues, and fiscal variables as a proportion of GDP. We define fiscal policy cyclicality as follows (see Table 2):

Table 2

Fiscal Indicators: Theoretical Correlations with the Business Cycle

\begin{tabular}{|c|c|c|c|c|c|c|c|}
\hline & $g$ & $\tau$ & $\begin{array}{c}\text { Tax } \\
\text { Revenues }\end{array}$ & $\begin{array}{l}\text { Primary } \\
\text { Balance }\end{array}$ & g/GDP & $\begin{array}{c}\text { Tax } \\
\text { Revenues/GDP }\end{array}$ & $\begin{array}{c}\text { Primary } \\
\text { Balance/ } \\
\text { GDP }\end{array}$ \\
\hline Countercyclical & - & + & + & + & - & $+/ 0 /-$ & $+/ 0 /-$ \\
\hline Procyclical & + & - & $+/ 0 /-$ & $+/ 0 /-$ & $+/ 0 /-$ & $+/ 0 /-$ & $+/ 0 /-$ \\
\hline Acyclical & 0 & 0 & + & + & - & $+/ 0 /-$ & $+/ 0 /-$ \\
\hline
\end{tabular}

i. A countercyclical fiscal policy involves lower (higher) government spending and higher (lower) tax rates in good (bad) times. We call such a policy countercyclical because it would tend to stabilize the business cycle (i.e., fiscal policy is contractionary in good times and expansionary in bad times). 
ii. A procyclical fiscal policy involves higher (lower) government spending and lower (higher) tax rates in good (bad) times. We call such a policy procyclical because it would tend to reinforce the business cycle (i.e., fiscal policy is expansionary in good times and contractionary in bad times). ${ }^{7}$

iii. An acyclical fiscal policy involves constant government spending and constant tax rates over the cycle (or, more precisely for the case of a stochastic world, government spending and tax rates do not vary systematically with the business cycle). We call such a policy acyclical because it neither reinforces nor stabilizes the business cycle.

The correlations implied by these definitions are shown in the first two columns of Table 2 .

We next turn to the implications of these cyclical definitions of fiscal policy for the behavior of tax revenues, the primary fiscal balance, and government expenditure, tax revenues, and primary balance as a proportion of GDP. ${ }^{8}$ In doing so, we will make use of the following two definitions:

$$
\text { Tax revenues }=\text { Tax rate } \times \text { tax base }
$$

\section{Primary balance $=$ Tax revenues - government expenditures (excluding interest payments)}

Consider first an acyclical fiscal policy. Since the tax rate is constant over the cycle and the tax base increases in good times and falls in bad times, tax revenues will have a positive correlation with the business cycle. This, in turn, implies that the primary balance will also be positively correlated with the cycle. The ratio of government expenditure (net of interest payments) to GDP will be negatively correlated with the cycle because government expenditure does not vary and, by definition, GDP is high (low) in good (bad) times. Given that tax revenues are higher (lower) in good (bad) times, the correlation

\footnotetext{
${ }^{7}$ It is important to notice that, under this definition, a procyclical fiscal policy implies a negative correlation between tax rates and output over the business cycle. Our terminology thus differs from the one in the real business cycle literature in which any variable positively (negatively) correlated with the output cycle is referred to as procyclical (countercyclical).

${ }^{8}$ It is worth emphasizing that, in deriving the theoretical correlations below, the only assumption made is that the tax base (output or consumption) is high in good times and low in bad times. This is true by definition in the case of output and amply documented for the case of consumption. Aside from this basic assumption, what follows is an accounting exercise that is independent of any particular model.
} 
of the ratio of tax revenues to GDP with the cycle is ambiguous (i.e., it could be positive, zero, or negative as indicated in Table 2). As a result, the correlation of the primary balance as a proportion of GDP with the cycle will also be ambiguous.

Consider procyclical fiscal policy. Since, by definition, the tax rate goes down (up) in good (bad) times but the tax base moves in the opposite direction, the correlation of tax revenues with the cycle is ambiguous. Since $g$ goes up in good times, the correlation of g/GDP can, in principle, take on any value. Given the ambiguous cyclical behavior of tax revenues, the cyclical behavior of tax revenues as a proportion of GDP is also ambiguous. The behavior of the primary balance as a proportion of GDP will also be ambiguous.

Lastly, consider countercyclical fiscal policy. By definition, tax rates are high in good times and low in bad times, which imply that tax revenues vary positively with the cycle. The same is true of the primary balance since tax revenues increase (fall) and government spending falls (increases) in good (bad) times. The ratio g/GDP will vary negatively with the cycle because g falls (increases) in good (bad) times. Since tax revenues increase in good times, the behavior of tax revenues as a proportion of GDP will be ambiguous and, hence, so will be the behavior of the primary balance as a proportion of GDP.

Several important observations follow from Table 2 regarding the usefulness of different indicators in discriminating among the three cases:

i. From a theoretical point of view, the best indicators to look at would be government spending and tax rates. By definition, these indicators would clearly discriminate among the three cases. As Table 2 makes clear, no other indicator has such discriminatory power. In practice, however, there is no systematic data on tax rates (other than perhaps the inflation tax rate), leaving us with government spending as the best indicator.

ii. The cyclical behavior of tax revenues will be useful only to the extent that it has a negative or zero correlation with the business cycle. This would be an unambiguous indication that fiscal policy is procyclical. It would signal a case in which the degree of procyclicality is so extreme that in, say, bad times, the rise in tax rates is so pronounced that it either matches or dominates the fall in the tax base. 
iii. The cyclical behavior of the primary balance will be useful only to the extent that it has a negative or zero correlation with the business cycle. This would be an unambiguous indication that fiscal policy is procyclical. It would indicate a case in which, in good times, the rise in government spending either matches or more than offsets a possible increase in tax revenues or a case in which a fall in tax revenues in good times reinforces the effect of higher government spending on the primary balance. Given our definition of fiscal policy cyclicality, it would be incorrect to infer that a primary deficit in bad times signals countercyclical fiscal policy. A primary deficit in bad times is, in principle, consistent with any of three cases. ${ }^{9}$

iv. The cyclical behavior of the primary balance as a proportion of GDP will never provide an unambiguous reading of the cyclical stance of fiscal policy. Interestingly, most of the literature (Gavin and Perotti (1997), Braun (2001), Dixon (2003), Lane (2003b), and Calderon and Schmidt-Hebbel (2003)) has drawn conclusions from looking at this indicator. For instance, Gavin and Perotti (1997) find that the response of the fiscal surplus as a proportion of GDP to a one-percentage-point increase in the rate of output growth is not statistically different from zero in Latin America and take this as an indication of procyclical fiscal policy. Calderon and Schmidt-Hebbel (2003), in contrast, find a negative effect of the output gap on deviations of the fiscal balance from its sample mean and interpret this as countercyclical fiscal policy. Given our definitions, however, one would not be able to draw either conclusion (as the last column of Table 2 makes clear).

$v$. The cyclical behavior of the ratio g/GDP will be useful only to the extent that it has a positive or zero correlation with the business cycle. This would be an unambiguous indication that fiscal policy is procyclical. In other words, finding that this ratio is negatively correlated with the cycle does not allow us

\footnotetext{
${ }^{9}$ By the same token, it would also seem unwise to define procyclical fiscal policy as a negative correlation between output and the fiscal balance (as sometimes done in the literature) since a zero or even positive correlation could also be consistent with procyclical fiscal policy, as defined above.
} 
to discriminate among the three cases. Once again, this suggests caution in interpreting some of the existing literature which relies on this indicator for drawing conclusions.

vi. Lastly, the cyclical behavior of the ratio of tax revenues to GDP will not be particularly useful in telling us about the cyclical properties of fiscal policy since its theoretical behavior is ambiguous in all three cases.

In sum, our discussion suggests that extreme caution should be exercised in drawing conclusions on policy cyclicality based either on the primary balance or on the primary balance, government spending, and tax revenues as a proportion of GDP. In light of this, we will only rely on indicators that, given our definition of procyclicality, provide an unambiguous measure of the stance of fiscal policy: government spending and -- as a proxy for a tax rate -- the inflation tax rate. ${ }^{10}$

From a theoretical point of view, there are various models that could rationalize different stances of fiscal policy over the business cycle. Countercyclical fiscal policy could be rationalized by resorting to a traditional Keynesian model (in old or new clothes) with an objective function that penalizes deviations of output from trend since an increase (reduction) in government spending and/or a reduction (increase) in tax rates would expand (contract) output. An acyclical fiscal policy could be rationalized by neoclassical models of optimal fiscal policy which call for roughly constant tax rates over the business cycle (see Chari and Kehoe (1999)). If government spending is endogeneized (by, say, providing direct utility), it would optimally behave in a similar way to private consumption and hence would be acyclical in the presence of complete markets (Riascos and Végh (2003)). Procyclical fiscal policy could be rationalized by resorting to political distortions (Tornell and Lane (1999) and Talvi and Végh (2000)), borrowing constraints (Gavin and Perotti (1997) and Aizeman, Gavin, and Hausmann (1996)), or incomplete markets (Riascos and Végh (2003)).

\footnotetext{
${ }^{10} \mathrm{We}$ are, of course, fully aware that there is certainly no consensus on whether the inflation tax should be thought of as "just another tax". While the theoretical basis for doing so goes back to Phelps (1973) and has been greatly refined ever since (see, for example, Chari and Kehoe (1999)), the empirical implications of inflation as an optimal tax have received mixed support (see Calvo and Végh (1999) for a discussion).
} 


\section{II.3 Monetary policy}

Performing the same conceptual exercise for monetary policy is much more difficult because (i) monetary policy instruments may depend on the existing exchange rate regime and (ii) establishing outcomes (i.e., determining the behavior of endogenous variables) requires the use of some (implicit) model.

For our purposes, it is enough to define two exchange rate regimes: fixed or predetermined exchange rates and flexible exchange rates (which we define as including any regime in which the exchange rate is allowed some flexibility). By definition, flexible exchange rate regimes include relatively clean floats (which are rare) and dirty floats (a more common type, as documented in Reinhart and Rogoff (2004)).

Under certain assumptions, a common policy instrument across these two different regimes would be a short-term interest rate. The most prominent example is the federal funds rate in the United States, an overnight interbank interest rate that constitutes the Federal Reserve's main policy target. From a theoretical point of view, under flexible exchange rates, monetary policy can certainly be thought of in terms of some short-term interest rate since changes in the money supply will directly influence interest rates. Under fixed or predetermined exchange rates, the only assumption needed for a short-term interest rate to also be thought of as a policy instrument is that there be some imperfect substitution between domestic and foreign assets (see Flood and Jeanne (2000) and Lahiri and Végh, (2003)). In fact, it is common practice for central banks to raise some short-term interest rate to defend a fixed (or more rigid) exchange rate.

In principle, then, observing the correlation between a policy-controlled short-term interest rate and the business cycle would indicate whether monetary policy is countercyclical (the interest rate is raised in good times and reduced in bad times, implying a positive correlation), procyclical (the interest rate is reduced in good times and increased in bad times, implying a negative correlation) or acyclical (the interest rate is not systematically used over the business cycle, implying no correlation), as indicated in Table 3. 
Table 3

Monetary Indicators: Theoretical Correlations with The Business Cycle

\begin{tabular}{|lcccc|}
\hline & $\begin{array}{c}\text { Short-Term } \\
\text { Interest Rate }\end{array}$ & $\begin{array}{c}\text { Rate of } \\
\text { Growth of } \\
\text { Central Bank } \\
\text { Domestic } \\
\text { Credit }\end{array}$ & $\begin{array}{c}\text { Real Money } \\
\text { Balances } \\
\text { (M1 and M2) }\end{array}$ & $\begin{array}{c}\text { Real Interest } \\
\text { Rate }\end{array}$ \\
\hline Countercyclical & + & - & $+/ 0 /-$ & $+/ 0 /-$ \\
Procyclical & - & + & + & - \\
Acyclical & 0 & 0 & + & - \\
\hline
\end{tabular}

The expected correlations with other monetary variables are more complex. In the absence of an active interest rate policy, we expect real money balances (in terms of any monetary aggregate) to be high in good times and low in bad times (i.e., positively correlated with the business cycle) and real interest rates to be lower in good times and high in bad times (i.e., negatively correlated with the cycle). ${ }^{11}$ A procyclical interest rate policy would reinforce this cyclical pattern. ${ }^{12}$ A countercyclical interest rate policy would in principle call for lower real money balances and higher real interest rates in good times relative to the benchmark of no activist policy. In principle, this leaning-against-the wind policy could be so effective as to render the correlation between real money balances and output zero or even negative and the correlation between real interest rates and the cycle zero or even positive (as indicated in Table 3). In sum - and as Table 3 makes clear - the cyclical behavior of real money balances and real interest rates will only be informative in a subset of cases:

\footnotetext{
${ }^{11}$ A negative correlation between real interest rates and output would arise in a standard endowment economy model (i.e., a model with exogenous output) in which high real interest rates today signal today's scarcity of goods relative to tomorrow. In a production economy driven by technology shocks, however, this relationship could have the opposite sign. In addition, demand shocks, in and of themselves, would lead to higher real interest rates in good times and vice versa. Given these different possibilities, any inferences drawn on the cyclical stance of monetary policy from the behavior of real interest rates should be treated with extreme caution.

${ }^{12}$ If, as part of a procyclical monetary policy, policymakers were lowering reserve requirements, this should lead to even higher real money balances.
} 
i. A negative or zero correlation between (the cyclical components of) real money balances and output would indicate countercyclical monetary policy. In this case, real money balances would fall in good times and rise in bad times. In contrast, a positive correlation is, in principle, consistent with any monetary policy stance.

ii. A positive or zero correlation between (the cyclical components of) the real interest rate and output would indicate countercyclical monetary policy. In this case, policy countercyclicality is so extreme that real interest rates increase in good times and fall in bad times. In contrast, a negative correlation is, in principle, consistent with any monetary policy stance.

Unfortunately, in practice, even large databases typically carry information on overnight or very short-term interest rates for only a small number of countries. Hence, the interest rates that one observes in practice are of longer maturities and thus include an endogenous cyclical component (for instance, the changes in inflationary expectations, term premiums, or risk premiums over the cycle). To the extent that the inflation rate tends to have a small positive correlation with the business cycle in industrial countries and a negative correlation with the business cycle in developing countries, there will be a bias towards concluding that monetary policy is countercyclical in industrial countries and procyclical in developing countries. To reduce this bias, we will choose interbank/overnight rates whenever possible.

A second policy instrument under either regime is the rate of growth of the central bank's domestic credit. Naturally, how much a given change in domestic credit affects the monetary base and, hence, interest rates will depend on the particular exchange rate regime. Under predetermined exchange rates and perfect substitution between domestic and foreign assets, the monetary approach to the balance of payments tells us that the change in domestic credit will be exactly undone by an opposite change in reserves. However, under imperfect substitution between domestic and foreign assets, a, say, increase in domestic credit will have some effect on the monetary base. The same is true under a dirty floating regime, since the change in reserves will not fully offset the change in domestic credit.

In this context, a countercyclical monetary policy would imply reducing the rate of domestic credit growth during good times and vice versa (i.e., a negative correlation). A procyclical monetary 
policy would imply increasing the rate of domestic credit growth during good times and vice versa (i.e., a positive correlation). An acyclical policy would not systematically vary the rate of growth of domestic credit over the business cycle. ${ }^{13}$ Of course, changes in domestic credit growth can be seen as the counterpart of movements in short-term interest rates, with a reduction (an increase) in domestic credit growth leading to an increase (reduction) in short-term interest rates.

In addition to computing the correlations indicated in the above table, we will attempt to establish whether monetary policy is procyclical, acyclical, or countercyclical by estimating Taylor rules for every country for which data are available (see Taylor (1993)). Following Clarida, Gali, and Gertler (1999), our specification takes the form:

$\mathrm{i}_{\mathrm{t}}=\alpha+\beta_{1}\left(\pi_{\mathrm{t}}-\underline{\pi}\right)+\beta_{2} \mathrm{y}_{\mathrm{t}}^{\mathrm{c}}$,

where $i_{t}$ is a policy-controlled short-term interest rate, $\pi_{t}-\underline{\pi}$ captures deviations of actual inflation from its sample average, $\underline{\pi}$, and $\mathrm{y}_{\mathrm{t}}^{\mathrm{c}}$ is the output gap, measured as the cyclical component of output (i.e., actual output minus trend) divided by actual output. The coefficient $\beta_{2}$ in equation (1) would indicate the stance of monetary policy over the business cycle (see Table 4) - over and above the monetary authority's concerns about inflation which are captured by the coefficient $\beta_{1}$.

\section{Table 4}

Taylor Rules

\begin{tabular}{|cc|}
\hline Nature of Monetary Policy & Expected Sign on $\boldsymbol{\beta}_{\mathbf{2}}$ \\
\hline Countercyclical & + and significant \\
Procyclical & - and significant \\
Acyclical & insignificant \\
\hline
\end{tabular}

\footnotetext{
${ }^{13}$ In practice, however, using domestic credit to measure the stance of monetary policy is greatly complicated by the fact that inflation (especially in developing countries) tends to be high and variable. Hence, a large growth rate does not always reflect expansionary policies. For this reason, in the empirical section we will restrict our attention to short-term nominal interest rates as a policy instrument.
} 
Several remarks are in order regarding equation (1). First, we are assuming that current inflation is a good predictor of future inflation. Second, we are assuming that the mean inflation rate is a good representation of some implicit/explicit inflation target on the basis that central banks deliver on average the inflation rate that they desire. Third, given potential endogeneity problems, the relation captured in equation (1) is probably best interpreted as a long-run cointegrating relationship. Fourth, since our estimation will be based on annual data, equation (1) does not incorporate the possibility of gradual adjustments of the nominal interest rate to some target interest rate. Fifth, by estimating equation (1) we certainly do not mean to imply that every country in our sample has followed some type of Taylor rule throughout the sample. Rather, we see it as a potentially useful way of characterizing the correlation between a short-term interest rate and the output gap once one controls for the monetary authority's implicit or explicit inflation target.

There are by now numerous studies that have estimated Taylor rules, though most are limited to developed countries. For example, for the United States, Japan, and Germany, Clarida, Gali and Gertler (1997) report that, in the post-1979 period, the inflation coefficient is significantly above one (indicating that in response to a rise in expected inflation, central banks raised nominal rates enough to raise real rates) and the coefficient on the output gap is significantly positive except for the United States. In other words - and using the terminology spelled out in Table 4 -- since 1979 Japan and Germany have pursued countercyclical monetary policy (lowering interest rates in bad times and increasing them in good times) but monetary policy in the United States has been acyclical. In the pre-1979 period, however, the Federal Reserve also pursued countercyclical monetary policy (see Clarida, Gertler, and Gali (1999)). For Peru, Moron and Castro (2000) - using the change in the monetary base as the dependent variable and adding an additional term involving the deviation of the real exchange rate from trend - find that monetary policy is countercyclical. For Chile, Corbo (2000) finds that monetary policy does not respond to output (i.e., is acyclical).

In terms of the theoretical literature, there has been extensive work on how to theoretically derive Taylor-type rules in the context of Keynesian models (see, for example, Clarida, Gertler, and Gali 
(1999)). This literature would rationalize countercyclical monetary policy on the basis that increases (decreases) in the output gap (i.e., actual minus trend output) call for higher (lower) short-term interest rates to reduce (boost) aggregate demand. Acyclical monetary policy could be rationalized in terms of neo-classical models of optimal monetary policy which call for keeping the nominal interest rate close to zero (see Chari and Kehoe (1999)). Collection costs for conventional taxes could optimally explain a positive - but still constant over the cycle - level of nominal interest rates (see Calvo and Végh (1999) and the references therein). Some of the stories put forward to explain procyclical fiscal policy mentioned above could also be used to explain procyclical monetary policy if the nominal interest rate is part of the policy set available to the Ramsey planner. Non-fiscal based explanations for procyclical monetary policy might include the need for defending the domestic currency under flexible exchange rates (Lahiri and Végh (2004)) -which in bad times would call for higher interest rates to prevent the domestic currency from depreciating further - and models in which higher interest rates may provide a signal of the policymaker's intentions (see Drazen (2000)). In these models, establishing "credibility" in bad times may call for higher interest rates.

\section{II.4 Measuring “good" and "bad” times}

Not all advanced economies have as clearly defined business cycle turning points as those established by the National Bureau of Economic Research (NBER) for the United States. For developing economies, where quarterly data for the national income accounts is at best recent and most often nonexistent, even less is known about economic fluctuations and points of inflexion. Thus, to pursue our goal of assessing the cyclical stance of capital flows and macroeconomic policies, we must develop some criterion that breaks down economic conditions into "good" and "bad" times. Taking an eclectic approach to sort out this issue, we will follow three different techniques: a non-parametric approach and two filtering techniques commonly used in the literature. 
The non-parametric approach consists in dividing the sample into episodes where annual real GDP growth is above the median ("good times") and those times where growth falls below the median ("bad times"). The relevant median or cutoff point is calculated on a country-by-country basis. We then compute the "amplitude" of the cycle in different variables by comparing the behavior of the variable in question in good and bad times. We should notice that, although growth below the median need not signal a recession, restricting the definition of recession to involve only periods where GDP growth is negative is too narrow a definition of bad times for countries which have rapid population growth (which encompasses the majority of our sample), rapid productivity growth, or countries that have seldom experienced a recession by NBER standards. This approach has the appeal that it is nonparametric and free from the usual estimation problems that arise when all the variables in question are potentially endogenous.

The other two approaches consist of decomposing each time series into its stochastic trend and cyclical component using two popular filters - the ubiquitous Hodrick-Prescott filter (HP) and the bandpass filter developed in Baxter and King (1999). After decomposing each series into its trend and cyclical component, we report a variety of pairwise correlations between the cyclical components of GDP, net capital inflows, and fiscal and monetary indicators for each of the four income groups. These correlations are used to establish contemporaneous comovements, but a fruitful area for future research would be to analyze potential temporal causal patterns.

\section{The Big Picture}

This section presents a visual overview of the main stylized facts that we have uncovered, leaving the more detailed analysis of the results for the following sections. ${ }^{14}$ Our aim here is to contrast OECD and developing (i.e., non-OECD) countries and synthesize our findings in terms of key stylized facts. It is

14 Our data set covers 104 countries for the period 1960-2003 (the starting date for each series varies across countries and indicators). See Appendix Table 1 for data sources and Appendix Table 2 for the list of countries. 
worth stressing that we are not trying to identify underlying "structural" parameters or "shocks" that may give rise to these empirical regularities, but merely trying to uncover "reduced-form" correlations hidden in the data. Our findings can be summarized in terms of four stylized facts.

\section{Stylized fact \# 1. Net capital inflows are procyclical in most OECD and developing countries.}

This is illustrated in Figure 1, which plots the correlation between the cyclical components of net capital inflows and GDP. As the plot makes clear, most countries exhibit a positive correlation, indicating that countries tend to borrow in good times and repay in bad times.

Stylized fact \# 2. With regard to fiscal policy, OECD countries are, by and large, either countercyclical or acyclical. In sharp contrast, developing countries are predominantly procyclical.

Figures 2 through 4 illustrate this critical difference in fiscal policy between advanced and developing economies. Figure 2 plots the correlation between the cyclical components of real GDP and real government spending. As is clear from the graph, most OECD countries have a negative correlation while most developing countries have a positive correlation. Figure 3 plots the difference between the percent change in real government spending when GDP growth is above the median (good times) and when it is below the median (bad times). This provides a measure of the amplitude of the fiscal policy cycle: large negative numbers suggest that the growth in real government spending is markedly higher in bad times (and thus policy is strongly countercyclical), while large positive numbers indicate that the growth in real government spending is markedly lower in bad times (and thus policy is strongly procyclical). In our sample, the most extreme case of procyclicality is given by Liberia, where the growth in real government spending is 32.4 percentage points higher in good times compared to bad times, whereas the most extreme cases of countercyclicality are Sudan and Denmark, where real government spending growth is over 7 percentage points lower during expansions. Furthermore, in addition to a more volatile cycle - and as Aguiar and Gopinath (2004) show for some of the larger emerging markets - the trend component of output is itself highly volatile, which would also be captured in this measure of amplitude. Finally, Figure 4 plots the correlation between the cyclical components of output and the inflation tax. A negative correlation indicates procyclical fiscal policy since it implies that 
the inflation tax rate is lower in good times. Figure 4 makes clear that most OECD countries exhibit a positive correlation (countercyclical policy) while most developing countries exhibit a negative correlation (procyclical policy).

Stylized fact \# 3. With regard to monetary policy, most OECD countries are countercyclical, while developing countries are mostly procyclical or acyclical.

This is illustrated in Figure 5 for nominal lending rates. This holds for other nominal interest rates (including various measures of policy rates), as described in the next section. We plot the lending rate because it is highly correlated with the policy rates but offers more comprehensive data coverage.

Stylized fact \# 4. In developing countries, the capital flow cycle and the macroeconomic policy cycle reinforce each other (we dub this positive relationship as the "when it rains, it pours" phenomenon).

Put differently, macroeconomic policies are expansionary when capital is flowing in and contractionary when capital is flowing out. This is illustrated in Figures 6 through 8 . Figure 6 shows that most developing countries exhibit a positive correlation between the cyclical components of government spending and net capital inflows, but there does not seem to be an overall pattern for OECD countries. In the same vein, Figure 7 shows that in developing countries the correlation between the cyclical components of net capital inflows and the inflation tax is mostly negative while no pattern is apparent for OECD countries. Lastly, Figure 8 shows a predominance of negative correlations between the cyclical components of net capital inflows and the nominal lending rate for developing countries, suggesting that the capital flow and the monetary policy cycle reinforce each other. The opposite appears to be true for OECD countries.

\section{Further Evidence on Business, CAPital Flows, And Policy CyCles}

This section examines in greater depth the four stylized facts presented in the preceding section by looking at alternative definitions of monetary and fiscal policy, using different methods to define the cyclical patterns in economic activity, international capital flows, and macroeconomic policies, and splitting the sample along several dimensions. In particular - and as discussed in Section II above - we 
will use three different approaches to define good and bad times: a non-parametric approach that allows us to quantify the amplitude of the cycles and two more standard filtering techniques: the HodrickPrescott filter and the band-pass filter.

\section{1 Capital flows}

Tables 5 through 7 present additional evidence on stylized fact \# 1 (i.e., net capital inflows are procyclical in most OECD and developing countries).

Table 5

Amplitude of the Capital Flow Cycle

\begin{tabular}{|l|c|c|c|}
\hline \multirow{2}{*}{ Countries } & \multicolumn{3}{|c|}{ Net Capital Inflows/GDP } \\
\cline { 2 - 4 } & Good Times & Bad Times & $\begin{array}{c}\text { Amplitude } \\
\text { (1)-(2) }\end{array}$ \\
\hline OECD & (1) & (2) & 0.1 \\
Middle-High Income & 0.5 & 0.4 & 1.4 \\
Middle-Low Income & 4.4 & 3.0 & 1.2 \\
Low Income & 4.2 & 3.0 & 0.3 \\
\hline
\end{tabular}

Notes: Capital inflows/GDP is expressed in percentage terms.

Good (bad) times are defined as those years in which GDP growth is above (below) the median.

Source: IMF, World Economic Outlook.

Table 5 shows that net capital inflows as a proportion of GDP tend to be larger in good times than in bad times for all groups of countries, which indicates procyclical net capital inflows (recall from Table 1 that a positive correlation between capital inflows as a proportion of GDP and real GDP implies procyclical net capital inflows). ${ }^{1516}$ The decline in capital inflows as a proportion of GDP in bad times is largest for the middle-high income economies (1.4 percent of GDP). This should come as no surprise

\footnotetext{
${ }^{15}$ Based on data for 33 poor countries over a 25 year period, Pallage and Robe (2001) conclude that foreign aid has also been procyclical, which is consistent with our overall message.

${ }^{16} \mathrm{We}$ also found that, for both groups of middle-income countries, the current account deficit is larger in good times than in bad times, which is consistent with procyclical capital flows.
} 
since this group of countries is noted for having on-and-off access to international private capital markets, partly due to a history of serial default. ${ }^{17}$

The behavior of international credit ratings, such as the Institutional Investor Index, also provides insights on capital market access. ${ }^{18}$ As discussed in Reinhart, Rogoff and Savastano (2003), at very low ratings (the low-income countries), the probability of default is sufficiently high that countries are entirely shut out of international private capital markets, while ratings at the high end of the spectrum are a sign of uninterrupted market access. These observations are borne out in Tables 6 and 7 . Table 6 shows that there is essentially no difference in credit ratings during good and bad times for the wealthy OECD economies and the low-income countries. The largest difference in ratings across good and bad times is for the middle-income countries, where ratings are procyclical (i.e., high in good times and low in bad times).

Table 6

International Credit Ratings

\begin{tabular}{|l|c|c|c|}
\hline \multirow{2}{*}{ Countries } & \multicolumn{3}{|c|}{ Institutional Investor Ratings } \\
\cline { 2 - 4 } & Good Times & Bad Times & $\begin{array}{c}\text { Amplitude } \\
\text { (1)-(2) }\end{array}$ \\
\hline OECD & $\mathbf{( 1 )}$ & $\mathbf{( 2 )}$ & 0.1 \\
Middle-High Income & 78.5 & 78.4 & 1.8 \\
Middle-Low Income & 42.2 & 40.4 & 2.1 \\
Low Income & 32.9 & 30.8 & 0.0 \\
\hline
\end{tabular}

Good (bad) times are defined as those years in which GDP growth is above (below) the median.

Sources: Institutional Investor and IMF, World Economic Outlook.

\footnotetext{
${ }^{17}$ See Reinhart, Rogoff, and Savastano (2003).

${ }^{18}$ The Institutional Investor ratings, which are compiled twice a year, are based on information provided by economists and sovereign risk analysts at leading global banks and securities firms. The ratings grade each country on a scale going from zero to 100 , with a rating of 100 given to countries which are perceived as having the lowest chance of defaulting on its government debt obligations.
} 
This "U-shaped" pattern is also evident in the volatility of the credit ratings. Table 7 presents basic descriptive statistics for growth and the Institutional Investor ratings. Not surprisingly, ratings are far more stable for OECD economies (the coefficient of variation is 0.06 ) but so is growth, with a coefficient of variation of 0.8 . Despite the fact that output is the most volatile for the group of low income economies (with a coefficient of variation of 1.6, or twice the level of the OECD group), its international ratings $(0.18)$ are more stable than those of middle income countries $(0.22$ and 0.23$)$.

Table 7

International Credit Ratings and Real GDP: Descriptive Statistics

\begin{tabular}{|c|c|c|c|c|}
\hline \multirow[b]{2}{*}{ Statistics } & \multicolumn{4}{|c|}{ Countries } \\
\hline & OECD & $\begin{array}{l}\text { Middle-High } \\
\text { Income }\end{array}$ & $\begin{array}{l}\text { Middle-Low } \\
\text { Income }\end{array}$ & $\begin{array}{c}\text { Low } \\
\text { Income }\end{array}$ \\
\hline \multicolumn{5}{|c|}{ Institutional Investor Index: 1979-2003 } \\
\hline Coefficient of variation & 0.06 & 0.22 & 0.23 & 0.18 \\
\hline Mean & 79.9 & 41.5 & 32.0 & 21.8 \\
\hline \multicolumn{5}{|c|}{ Real GDP Growth: $1960-2003$} \\
\hline Coefficient of variation & 0.80 & 1.20 & 1.20 & 1.60 \\
\hline Mean & 3.90 & 4.90 & 4.70 & 3.30 \\
\hline
\end{tabular}

Sources: Institutional Investor and IMF, World Economic Outlook.

Finally, Table 8 presents correlations (using our two different filters) between the cyclical components of real GDP and net capital inflows. ${ }^{19}$ The correlations are positive and significant for all four groups of countries and for both filters. Not surprisingly, the correlations are the highest for OECD and middle-high income countries and the lowest for low income countries. These results thus strongly support the idea that capital inflows are indeed procyclical for both industrial and developing countries.

${ }^{19}$ Tables 8, 10,12, and 14 report the average country correlation for the indicated group of countries. We use a standard t-test to ascertain where the average is significantly different from zero. 
Table 8

Correlations between the Cyclical Components

of Net Capital Inflows and Real GDP

\begin{tabular}{|l|c|c|}
\hline \multirow{2}{*}{ Countries } & \multicolumn{2}{|c|}{ Correlations } \\
\cline { 2 - 3 } & HP Filter & Band-Pass Filter \\
\hline & & \\
OECD & $0.30^{*}$ & $0.25^{*}$ \\
Middle-High Income & $0.35^{*}$ & $0.26^{*}$ \\
Middle-Low Income & $0.24^{*}$ & $0.20^{*}$ \\
Low Income & $0.16^{*}$ & $0.10^{*}$ \\
\hline
\end{tabular}

Note: An asterisk denotes statistical significance at the 10 percent level. Sources: IMF, International Financial Statistics and World Economic Outlook.

\section{IV.2 Fiscal policy}

With regard to Stylized fact \# 2 (i.e., fiscal policy in OECD countries is, by and large, either countercyclical or acyclical while in developing countries fiscal policy is predominantly procyclical), Table 9 provides a measure of the amplitude of the fiscal policy cycle by showing - for six different measures of government spending - the difference between the change in real government spending when GDP growth is above the median and when it is below the median. Under this definition, a positive amplitude indicates procyclical government spending. The inflation tax is also included as the remaining fiscal indicator, with a negative amplitude denoting a procyclical tax rate. As argued in section 2, government spending and the inflation tax rate provide the best indicators to look at in terms of their ability to discriminate among different cyclical policy stances (recall Table 3). Other indicators - such as fiscal balances or tax revenues - convey less information.

The striking aspect of Table 9 is that, as shown in the last column, the amplitude of the fiscal spending cycle for non-OECD countries is considerably large for all measures of government spending. This suggests that, in particular for the two middle income groups, fiscal policy is not only procyclical, but markedly so. In contrast, while positive, the analogous figures for OECD countries are quite small, suggesting, on average, an acyclical fiscal policy. 
Table 9

Amplitude of the Fiscal Policy Cycle

\begin{tabular}{|c|c|c|c|}
\hline \multirow[b]{2}{*}{ Fiscal Indicators } & \multicolumn{3}{|c|}{ Increase in the Fiscal Indicator } \\
\hline & $\begin{array}{c}\text { Good Times } \\
\text { (1) }\end{array}$ & $\begin{array}{c}\text { Bad Times } \\
\text { (2) }\end{array}$ & $\begin{array}{l}\text { Amplitude } \\
\text { (1)-(2) }\end{array}$ \\
\hline \multicolumn{4}{|c|}{ OECD Countries } \\
\hline \multicolumn{4}{|l|}{ Central government: } \\
\hline Expenditure (WEO) & 3.4 & 3.1 & 0.3 \\
\hline Current expenditure minus interest payments & 4.2 & 2.8 & 1.4 \\
\hline Expenditure on goods and services & 3.0 & 2.0 & 1.0 \\
\hline Expenditure on wages and salaries & 2.6 & 1.3 & 1.3 \\
\hline \multicolumn{4}{|l|}{ General or consolidated government: } \\
\hline Expenditure (WEO) & 3.6 & 3.2 & 0.4 \\
\hline Current expenditure minus interest payments & 4.1 & 3.5 & 0.6 \\
\hline Inflation tax, $\pi /(1+\pi)$ & 4.5 & 5.4 & -0.9 \\
\hline \multicolumn{4}{|c|}{ Middle-High Income Countries } \\
\hline \multicolumn{4}{|l|}{ Central government: } \\
\hline Expenditure (WEO) & 8.1 & 0.0 & 8.1 \\
\hline Current expenditure minus interest payments & 9.6 & -0.1 & 9.7 \\
\hline Expenditure on goods and services & 8.1 & -0.3 & 8.4 \\
\hline Expenditure on goods and services & 8.3 & 0.4 & 7.9 \\
\hline \multicolumn{4}{|l|}{ General or consolidated government: } \\
\hline Expenditure (WEO) & 6.9 & -0.1 & 7.0 \\
\hline Current expenditure minus interest payments & 7.6 & 1.8 & 5.8 \\
\hline Inflation tax, $\pi /(1+\pi)$ & 10.9 & 13.1 & -2.2 \\
\hline \multicolumn{4}{|c|}{ Middle-Low Income Countries } \\
\hline \multicolumn{4}{|l|}{ Central government: } \\
\hline Expenditure (WEO) & 6.7 & 2.7 & 4.0 \\
\hline Current expenditure minus interest payments & 9.3 & 3.1 & 6.2 \\
\hline Expenditure on goods and services & 9.7 & 3.6 & 6.1 \\
\hline Expenditure on goods and services & 8.9 & 4.2 & 4.7 \\
\hline \multicolumn{4}{|l|}{ General or consolidated government: } \\
\hline Expenditure (WEO) & 6.4 & 2.5 & 3.9 \\
\hline Current expenditure minus interest payments & 8.5 & -2.1 & 10.6 \\
\hline Inflation tax, $\pi /(1+\pi)$ & 8.7 & 10.1 & -1.4 \\
\hline \multicolumn{4}{|c|}{ Low Income Countries } \\
\hline \multicolumn{4}{|l|}{ Central government: } \\
\hline Expenditure (WEO) & 8.3 & -0.2 & 8.5 \\
\hline Current expenditure minus interest payments & 5.0 & 0.5 & 4.5 \\
\hline Expenditure on goods and services & 5.1 & 0.6 & 4.5 \\
\hline Expenditure on wages and salaries & 4.0 & 0.8 & 3.2 \\
\hline \multicolumn{4}{|l|}{ General or consolidated government: } \\
\hline Expenditure (WEO) & 7.3 & -0.5 & 7.8 \\
\hline Current expenditure minus interest payments & 5.7 & -0.4 & 6.1 \\
\hline Inflation tax, $\pi /(1+\pi)$ & 9.4 & 12.4 & -3.0 \\
\hline
\end{tabular}

Notes: All data are from International Monetary Fund, Government Financial Statistics unless otherwise noted.

The increase for the fiscal spending indicators is the average annual real rate of growth expressed in percentage terms.

The inflation tax figure is multiplied by one hundred. The increase in the inflation tax denotes the average

change in this indicator.

Good (bad) times are defined as those years with GDP growth above (below) the median.

Sources: IMF, Government Financial Statistics and World Economic Outlook (WEO) 
Furthermore, based on the country-by-country computations of the amplitude of the fiscal spending cycle underlying Table 9 (which are illustrated in Figure 3), the conclusion that non-OECD countries are predominantly procyclical is overwhelming. For instance, for real central government expenditure, 94 percent of low-income countries exhibit a positive amplitude. For middle-low income countries this figure is 91 percent. Remarkably, every single country in the middle-high income category registers as procyclical. In contrast, when it comes to OECD countries, there is an even split between procyclical and countercyclical countries.

Turning to the inflation tax rate, $\pi /(1+\pi)$, it registers as procyclical in all of the four groups. The amplitude is the largest for the low income group ( 3 percentage points and the smallest for OECD countries (0.9 percentage point) ${ }^{20}$ Not surprisingly, the increase in the inflation tax rate is the highest during recessions (13.1 percent) for the middle-high income countries (which include chronic high inflation countries like Argentina, Brazil, and Uruguay) and lowest for the OECD at 5.4 percent.

Table 10 presents the pairwise correlations for the expenditure measures shown in Table 9 as well as for the inflation tax rate. With regard to the correlations between the cyclical components of GDP and government expenditure, the most salient feature of the results presented in Table 10 is that for the three developing country groups, all of the 36 correlations reported in Table 10 (18 correlations per filter) are positive irrespective of the expenditure series used or the type of filter. By contrast, all of the 12 correlations reported for the OECD are negative (though low). This is not to say that the relationship between the fiscal expenditure and business cycle is an extremely tight one (several entries in Table 10 show low correlations that are not significantly differently from zero-consistent with an acyclical pattern as defined in Table 2). However, when one examines these results, it becomes evident that for nonOECD countries (at least according to this exercise), fiscal policy is squarely procyclical. ${ }^{21}$

\footnotetext{
${ }^{20}$ Figures on the inflation tax are multiplied by one hundred.

${ }^{21}$ In terms of the country-by-country computations underlying Table 10, it is worth noting that for, say, real central government expenditure, 91 percent of the correlations for developing countries are positive (indicating procyclical
}

(continued) 
Table 10

Correlations between Fiscal Policy, Real GDP, and Net Capital Inflows

\begin{tabular}{|c|c|c|c|c|c|c|c|}
\hline \multirow[b]{2}{*}{ Countries } & \multicolumn{4}{|c|}{ Central Government } & \multirow{2}{*}{$\begin{array}{c}\text { General } \\
\text { Government } \\
\text { Expenditure }\end{array}$} & \multirow{2}{*}{$\begin{array}{c}\text { Consolidated } \\
\text { Government } \\
\text { Expenditure } \\
\text { Minus Interest } \\
\text { Payments }\end{array}$} & \multirow[b]{2}{*}{$\begin{array}{c}\text { Inflation } \\
\text { Tax }\end{array}$} \\
\hline & Expenditure & $\begin{array}{c}\text { Expenditure } \\
\text { Minus } \\
\text { Interest } \\
\text { Payments }\end{array}$ & $\begin{array}{c}\text { Expenditure } \\
\text { on } \\
\text { Goods and } \\
\text { Services } \\
\end{array}$ & $\begin{array}{c}\text { Expenditure } \\
\text { on Wages } \\
\text { and } \\
\text { Salaries }\end{array}$ & & & \\
\hline \multicolumn{8}{|c|}{ HP Filter } \\
\hline \multicolumn{8}{|c|}{ Correlation with Real GDP } \\
\hline OECD & $-0.13 *$ & -0.05 & -0.06 & $-0.15^{*}$ & -0.06 & -0.07 & $0.16^{*}$ \\
\hline Middle-High Income & $0.38 *$ & 0.10 & 0.08 & 0.01 & $0.43^{*}$ & 0.10 & $-0.15^{*}$ \\
\hline Middle-Low Income & $0.22 *$ & 0.13 & 0.07 & 0.03 & $0.20 *$ & 0.12 & $-0.09 *$ \\
\hline Low Income & $0.38 *$ & $0.24 *$ & $0.54 *$ & $0.59 *$ & $0.37 *$ & $0.17^{*}$ & $-0.20 *$ \\
\hline \multicolumn{8}{|c|}{ Correlation with Net Capital Inflows } \\
\hline OECD & 0.03 & 0.05 & 0.04 & 0.04 & 0.09 & 0.03 & 0.04 \\
\hline Middle-High Income & $0.25 *$ & $0.22 *$ & $0.28 *$ & $0.27 *$ & $0.25 *$ & $0.20 *$ & $-0.31 *$ \\
\hline Middle-Low Income & $0.16^{*}$ & 0.11 & 0.13 & 0.12 & $0.18^{*}$ & 0.13 & $-0.14^{*}$ \\
\hline Low Income & $0.20^{*}$ & 0.05 & 0.20 & 0.37 & $0.24 *$ & -0.16 & $-0.09 *$ \\
\hline \multicolumn{8}{|c|}{ Band-Pass Filter } \\
\hline \multicolumn{8}{|c|}{ Correlation with Real GDP } \\
\hline OECD & -0.05 & $-0.15^{*}$ & -0.11 & $-0.20 *$ & -0.02 & -0.12 & $0.15^{*}$ \\
\hline Middle-High Income & $0.53 *$ & $0.19 *$ & $0.23 *$ & 0.13 & $0.44 *$ & $0.23 *$ & $-0.13 *$ \\
\hline Middle-Low Income & $0.29 *$ & $0.29 *$ & $0.26^{*}$ & $0.23 *$ & $0.23 *$ & $0.23 *$ & $-0.10^{*}$ \\
\hline Low Income & $0.46^{*}$ & $0.42 *$ & $0.53^{*}$ & $0.59 *$ & $0.34 *$ & $0.32 *$ & $-0.16^{*}$ \\
\hline \multicolumn{8}{|c|}{ Correlation with Net Capital Inflows } \\
\hline OECD & 0.07 & 0.08 & 0.05 & 0.04 & $0.14 *$ & 0.00 & 0.02 \\
\hline Middle-High Income & $0.19^{*}$ & 0.12 & $0.28^{*}$ & $0.25^{*}$ & $0.16^{*}$ & 0.09 & $-0.25^{*}$ \\
\hline Middle-Low Income & $0.14^{*}$ & 0.08 & 0.05 & 0.10 & $0.16^{*}$ & 0.11 & $-0.10^{*}$ \\
\hline Low Income & $0.19 *$ & $0.25 *$ & $0.27^{*}$ & $0.39^{*}$ & $0.22 *$ & 0.13 & $-0.07 *$ \\
\hline
\end{tabular}

Notes: An asterisk denotes statistical significance at the 10 percent level.

Source: IMF, World Economic Outlook. 
In terms of the inflation tax, the results for both filters coincide: the correlation between the cyclical components of GDP and the inflation tax is positive and significant for OECD countries (indicating countercyclical fiscal policy) and negative and significant for all groups of developing countries (indicating procyclical fiscal policy).

Table 10 also presents evidence on the relationship between capital inflows and fiscal policy. Our premise is that the capital flow cycle may affect macroeconomic policies in developing countries, particularly in the highly volatile economies that comprise the middle-high income countries. To this end, we report the correlations (using both the HP and bandpass filters) of the cyclical components of the fiscal variables and net capital inflows. Remarkably, all but one of the 36 correlations (18 per filter) for nonOECD countries are positive with 21 of them being significantly different from zero. This provides clear support for the idea that the fiscal spending cycle is positively linked to the capital flow cycle (Stylized fact \#4.) The evidence is particularly strong for middle-high income countries (with 10 out of the 12 positive correlations being significant). We do not pretend, of course, to draw inferences on causality from pairwise correlations, but it is not unreasonable to expect that a plausible causal relationship may run from capital flows to fiscal spending — an issue that clearly warrants further study. More surprising is the evidence suggesting that the relationship between the fiscal spending cycle and capital flows is also important for low income countries (most of which have little access to international capital markets). It may be fruitful to explore to what extent this result may owe to links between cycles in commodity prices and government expenditure. ${ }^{22}$ In sharp contrast to developing countries, the correlations for OECD countries are - with only one exception - never significantly different from zero, which suggests that there is no link between the capital flow cycle and fiscal spending.

fiscal policy) whereas 65 percent of the correlations for OECD countries are negative (indicating countercyclical fiscal policy), as illustrated in Figure 2.

${ }^{22}$ In this regard, see Cuddington (1989). 
Table 10 also indicates that the inflation tax is significantly and negatively correlated with the capital flow cycle for all developing countries (and both filters). Our conjecture is that inflation provides a form of alternative financing when international capital market conditions deteriorate. For OECD countries, this correlation is not significantly different from zero.

\section{IV.3. Monetary policy}

To document Stylized fact \# 3 (i.e., monetary policy is countercyclical in most OECD countries while it is mostly procyclical in developing ones), we perform the same kind of exercises carried out for the fiscal indicators but, in addition, we also estimate variants of the Taylor rule, as described in Section II.

Table 11 presents the same exercise performed in Table 9 for the five nominal interest rate series used in this study. As discussed in Section II, a short-term policy instrument, such as the interbank rate (or in some countries the T-bill or discount rate), is the best indicator of the stance of monetary policy. In this case, a negative amplitude denotes procyclical monetary policy. The difference between the OECD countries and the other groups is striking. For the OECD countries, interest rates decline in recessions and increase in expansions (for example, the interbank interest rate falls on average 0.7 percent or 70 basis points during recessions). In sharp contrast, in non-OECD countries, most of the nominal interest rates decline in expansions and increase in recessions (for instance, interbank rates in middle high income countries rise by 2.3 percent or 230 basis points in recessions). Thus the pattern for the non-OECD group is broadly indicative of procyclical monetary policy. ${ }^{23}$

\footnotetext{
${ }^{23}$ Appendix Tables 3 and 4 show results analogous to those in Table 11 for real interest rates and real monetary aggregates, respectively. Broadly speaking, real rates for OECD countries show a positive correlation with the cycle (i.e., they generally rise in good times and fall in bad times). This is, in principle, consistent with countercyclical monetary policy (recall Table 3). In contrast, for middle high and middle low income countries, real interest rates appear to be negatively correlated with the cycle. These results are consistent with those reported in Neumeyer and Perri (2004). The results for low income countries are harder to interpret as they are more similar to those for OECD countries. The results for real money balances in Appendix Table 4 are in line with our priors - with real money balances rising more in good times than in bad times. This positive correlation, however, does not allow us to draw any inference on the stance of monetary policy (recall Table 3).
} 
Table 11

Amplitude of the Monetary Policy Cycle

\begin{tabular}{|c|c|c|c|}
\hline \multirow[b]{2}{*}{ Interest Rate } & \multicolumn{3}{|c|}{ Increases in Nominal Interest Rates } \\
\hline & $\begin{array}{c}\text { Good Times } \\
\text { (1) }\end{array}$ & $\begin{array}{c}\text { Bad Times } \\
\text { (2) }\end{array}$ & $\begin{array}{l}\text { Amplitude } \\
\text { (1)-(2) }\end{array}$ \\
\hline \multicolumn{4}{|c|}{ OECD Countries } \\
\hline Interbank rate & 0.3 & -0.7 & 1.0 \\
\hline Treasury bill rate & 0.2 & -0.4 & 0.6 \\
\hline Discount rate & 0.5 & -0.5 & 1.0 \\
\hline Lending rate & 0.0 & -0.3 & 0.3 \\
\hline Deposit rate & 0.1 & -0.3 & 0.4 \\
\hline \multicolumn{4}{|c|}{ Middle-High Income Countries } \\
\hline Interbank rate * & -2.2 & 2.3 & -4.5 \\
\hline Treasury bill rate & -2.6 & -1.5 & -1.1 \\
\hline Discount rate & -1.5 & 2.7 & -4.2 \\
\hline Lending rate & -4.0 & 2.1 & -6.1 \\
\hline Deposit rate * & 0.7 & 1.0 & -0.3 \\
\hline \multicolumn{4}{|c|}{ Middle-Low Income Countries } \\
\hline Interbank rate & -0.8 & -0.1 & -0.7 \\
\hline Treasury bill rate & -0.7 & 1.1 & -1.8 \\
\hline Discount rate & 0.5 & 0.5 & 0.0 \\
\hline Lending rate & -1.0 & 0.4 & -1.4 \\
\hline Deposit rate & -0.5 & -0.5 & 0.0 \\
\hline \multicolumn{4}{|c|}{ Low Income Countries } \\
\hline Interbank rate & -1.3 & 1.5 & -2.8 \\
\hline Treasury bill rate & -1.0 & 0.5 & -1.5 \\
\hline Discount rate* & -0.8 & 0.2 & -1.0 \\
\hline Lending rate & -4.7 & 0.2 & -4.9 \\
\hline Deposit rate* & -1.6 & 0.2 & -1.8 \\
\hline
\end{tabular}

Notes: Increases in interest rates are defined as the average annual change in interest rates (with interest rates expressed in percentage points)

Good (bad) times are defined as those years with GDP growth above (below) the median.

* The median is reported in lieu of the average, as the average is distorted by one or more very high inflation (or hyperinflation) episodes.

Sources: IMF, World Economic Outlook and International Financial Statistics. 
Table 12 presents the correlations of the cyclical components of real GDP, capital inflows, and the five nominal interest rates introduced in the previous table. In terms of the cyclical stance of monetary policy, the evidence seems the most compelling for OECD countries (countercyclical monetary policy), where all 10 correlations are positive and seven significantly so. There is also evidence to suggest procyclical monetary policy in middle-high income countries (all ten correlations are negative and four significantly so). The evidence is more mixed for the other two groups of countries where the lack of statistical significance partly reflects the fact that they have relative shorter time series on interest rates. ${ }^{24}$

Turning to the correlations between net capital inflows and interest rates in Table 12, the evidence is again strongest for the OECD countries (with all 10 correlations significantly positive), clearly indicating that higher interest rates are associated with capital inflows. For middle-high income countries, 8 out of the 10 correlations are negative but not significantly different from zero (again, shorter time series are an important drawback). Still, we take this as suggestive evidence of the when-it-rains-it-pours syndrome.

Given the notorious difficulties (present even for advanced countries such as the United States) in empirically characterizing the stance of monetary policy, we performed a complementary exercise as a robustness check for all income groups. Specifically, we estimated the Taylor rule specified in Section II. Table 13 reports the results for the three nominal interest rates that are, at least in principle, more likely to serve as policy instruments (interbank, T-bill, and discount.) Recalling that countercyclical policy requires a positive and significant $\beta_{2}$, the main results are as follows. ${ }^{25}$ First, monetary policy in OECD countries appears to be countercyclical (as captured by positive and significant coefficients in two out of the three specifications). Second, there is some evidence of monetary policy procyclicality in middle-

\footnotetext{
${ }^{24}$ It is important to warn the reader that the data on interest rates for non-OECD countries is spotty and rather incomplete. Our results should thus be interpreted with caution and as merely suggestive.

${ }^{25}$ As an aside, notice that the coefficient on the inflation gap is always positive and significant.
} 
Table 12

Correlations between Monetary Policy, Real GDP, and Net Capital Inflows

\begin{tabular}{|c|c|c|c|c|c|}
\hline \multirow[t]{2}{*}{ Countries } & \multicolumn{5}{|c|}{ Nominal Interest Rates } \\
\hline & Interbank & T-bill & Discount & Lending & Deposit \\
\hline \multicolumn{6}{|c|}{ HP Filter } \\
\hline \multicolumn{6}{|c|}{ Correlation with Real GDP } \\
\hline OECD & $0.28 *$ & $0.39 *$ & $0.37 *$ & $0.23 *$ & $0.21 *$ \\
\hline Middle-High Income & $-0.24 *$ & -0.09 & -0.02 & $-0.24 *$ & $-0.21 *$ \\
\hline Middle-Low Income & 0.02 & 0.00 & 0.04 & 0.07 & 0.01 \\
\hline Low Income & -0.12 & -0.02 & 0.04 & -0.02 & -0.10 \\
\hline \multicolumn{6}{|c|}{ Correlation with Net Capital Inflows } \\
\hline OECD & $0.14^{*}$ & $0.25^{*}$ & $0.20 *$ & $0.19 *$ & $0.11 *$ \\
\hline Middle-High Income & -0.11 & -0.24 & 0.11 & -0.13 & -0.09 \\
\hline Middle-Low Income & 0.04 & 0.03 & 0.07 & 0.05 & 0.00 \\
\hline Low Income & 0.01 & 0.06 & 0.03 & -0.11 & 0.05 \\
\hline \multicolumn{6}{|c|}{ Band-Pass Filter } \\
\hline \multicolumn{6}{|c|}{ Correlation with Real GDP } \\
\hline OECD & 0.12 & $0.13 *$ & $0.23 *$ & 0.01 & 0.06 \\
\hline Middle-High Income & -0.23 & -0.14 & -0.10 & -0.10 & $-0.13 *$ \\
\hline Middle-Low Income & $0.19 *$ & 0.00 & -0.03 & 0.03 & -0.03 \\
\hline Low Income & -0.09 & -0.04 & -0.07 & -0.07 & -0.08 \\
\hline \multicolumn{6}{|c|}{ Correlation with Net Capital Inflows } \\
\hline OECD & $0.16^{*}$ & $0.28 *$ & $0.19 *$ & $0.16^{*}$ & $0.13 *$ \\
\hline Middle-High Income & -0.05 & -0.17 & 0.08 & -0.18 & -0.11 \\
\hline Middle-Low Income & $0.30 *$ & -0.03 & 0.11 & 0.00 & -0.07 \\
\hline Low Income & 0.12 & 0.07 & 0.02 & -0.11 & 0.04 \\
\hline
\end{tabular}

Notes: An asterisk denotes statistical significance at the 10 percent level.

Sources: IMF, World Economic Outlook and International Financial Statistics. 
Table 13

Taylor Rules

\begin{tabular}{|c|c|c|c|}
\hline \multicolumn{4}{|c|}{$\begin{array}{l}\text { Regression } i_{t}=\alpha+\beta_{1}\left(\pi_{t}-\underline{\pi}\right)+\beta_{2} y_{t}^{c}+u_{t} \\
i_{t}=\text { Short term interest rate. Definitions of the rates are given below. } \\
\pi_{t}-\underline{\pi}=\text { Inflation rate minus sample mean. } \\
y_{t}^{c}=\text { Cyclical component of real GDP (HP filter) divided by actual output }\end{array}$} \\
\hline $\begin{array}{l}\text { Dependent variable } \\
\text { (number of observations) }\end{array}$ & $\beta_{1}$ & $\boldsymbol{\beta}_{2}$ & $\mathbf{R}^{2}$ \\
\hline \multicolumn{4}{|c|}{ OECD Countries } \\
\hline Interbank rate (663) & $0.56^{*}$ & 0.02 & 0.27 \\
\hline T-bill rate $(503)$ & $0.60^{*}$ & $0.12 *$ & 0.39 \\
\hline Discount rate (758) & $0.49 *$ & $0.15^{*}$ & 0.25 \\
\hline \multicolumn{4}{|c|}{ Middle-High Income Countries } \\
\hline Interbank rate (187) & $4.84^{*}$ & -0.31 & 0.48 \\
\hline T-bill rate $(152)$ & $0.32 *$ & $-0.12 *$ & 0.04 \\
\hline Discount rate (413) & $0.43^{*}$ & -0.11 & 0.01 \\
\hline \multicolumn{4}{|c|}{ Middle-Low Income Countries } \\
\hline Interbank rate (250) & $0.81^{*}$ & -0.19 & 0.34 \\
\hline T-bill rate $(218)$ & $0.44 *$ & $-0.27 *$ & 0.11 \\
\hline Discount rate (686) & $1.21^{*}$ & 0.26 & 0.42 \\
\hline \multicolumn{4}{|c|}{ Low Income Countries } \\
\hline Interbank rate (282) & $0.38^{*}$ & $0.18^{*}$ & 0.09 \\
\hline T-bill rate $(258)$ & $0.29 *$ & 0.11 & 0.17 \\
\hline Discount rate (951) & $6.03 *$ & 1.59 & 0.22 \\
\hline
\end{tabular}

Notes: The equations have been estimated using panel data with fixed effects.

* Denotes significance at the 10 percent level.

Sources: IMF, World Economic Outlook and International Financial Statistics. 
income countries (as captured by the negative and significant coefficients for the T-bill regressions). This overall message is thus broadly consistent with that of Tables 11 and 12.

\section{IV.4 Exchange rate arrangements, capital market integration, and crises}

In the remainder of this section, we divide the sample along three different dimensions in order to assess whether our results are affected by the degree of capital mobility in the world economy, the existing exchange rate regime, and the presence of crises. First, to examine whether the increased capital account integration of the more recent past has affected the cyclical patterns of the variables of interest, we split our sample into two subperiods (1960-1979 and 1980-2003) and performed all the exercises described earlier in this section. Second, we break up the sample according to a rough measure of the de facto degree of exchange rate flexibility. Lastly, we split the sample into currency crisis periods and tranquil periods. This enables us to ascertain whether our results on procyclicality are driven to some extent by the more extreme crises episodes. The results for each of these partitions - which are presented in Table 14 -- will be discussed in turn. ${ }^{26}$

\section{a. 1960-1979 versus 1980-2003}

The four main results that emerge from dividing the sample into 1960-1979 and 1980-2003 are the following. First, capital flows are consistently procyclical in both periods, with the correlation increasing in the latter period for middle-high income countries. Second, the cyclical stance of government spending does not appear to change across periods for non-OECD countries (i.e., fiscal policy is procyclical in both periods) but OECD countries appear to have been acyclical in the pre-1980 period and turn countercyclical in the post-1980 period. Third, the inflation tax appears to be essentially acyclical in the pre-1980 period only to turn significantly countercyclical for OECD countries and

\footnotetext{
${ }^{26}$ To conserve on space, Table 14 presents results for only one measure of government spending and one interest rate using the HP filter. The remaining results are available upon request from the authors.
} 
Table 14

Cyclical Characteristics of Net Capital Inflows, Fiscal Policy, and Monetary Policy

\begin{tabular}{|c|c|c|c|c|c|c|c|c|}
\hline \multirow[b]{3}{*}{ Countries } & \multicolumn{8}{|c|}{ Correlation with Real GDP } \\
\hline & \multirow{2}{*}{\multicolumn{2}{|c|}{ Net Capital Inflows }} & \multicolumn{4}{|c|}{ Fiscal Policy } & \multirow{2}{*}{\multicolumn{2}{|c|}{$\begin{array}{c}\text { Monetary Policy } \\
\text { Lending Rate }\end{array}$}} \\
\hline & & & $\begin{array}{r}\text { Central G } \\
\text { Expe } \\
\end{array}$ & $\begin{array}{l}\text { vernment } \\
\text { dditure }\end{array}$ & Inflat & ion Tax & & \\
\hline & Pre-1980 & Post-1980 & Pre-1980 & Post-1980 & Pre-1980 & Post-1980 & Pre-1980 & Post-1980 \\
\hline OECD & $\mathrm{n} / \mathrm{a}$ & $0.38 *$ & -0.19 & $-0.14 *$ & 0.11 & $0.22 *$ & 0.04 & $0.25^{*}$ \\
\hline Middle-High Income & $0.25 *$ & $0.38 *$ & $0.43 *$ & $0.33 *$ & -0.04 & $-0.16 *$ & $\mathrm{n} / \mathrm{a}$ & $-0.23 *$ \\
\hline Middle-Low Income & $0.28 *$ & $0.26^{*}$ & $0.39 *$ & $0.19 *$ & -0.01 & $-0.12 *$ & $\mathrm{n} / \mathrm{a}$ & 0.03 \\
\hline \multirow[t]{2}{*}{ Low Income } & $0.20 *$ & $0.17 *$ & $0.43^{*}$ & $0.38 *$ & -0.08 & $-0.23 *$ & $\mathrm{n} / \mathrm{a}$ & 0.03 \\
\hline & Fix & Flex & Fix & Flex & Fix & Flex & Fix & Flex \\
\hline OECD & $0.35 *$ & $0.40 *$ & -0.09 & -0.19 & 0.11 & $0.26 *$ & 0.13 & $0.38 *$ \\
\hline Middle-High Income & $0.39 *$ & $0.35 *$ & $0.39 *$ & $0.22 *$ & $-0.15 *$ & $-0.26^{*}$ & -0.12 & -0.06 \\
\hline Middle-Low Income & $0.21 *$ & $0.34 *$ & $0.24 *$ & $0.31 *$ & 0.04 & $-0.15^{*}$ & 0.06 & $0.29 *$ \\
\hline \multirow[t]{2}{*}{ Low Income } & $0.27 *$ & $0.20 *$ & $0.40^{*}$ & $0.28 *$ & $-0.13 *$ & $-0.21 *$ & -0.01 & 0.01 \\
\hline & $\begin{array}{l}\text { Crisis } \\
\text { n/a }\end{array}$ & $\begin{array}{c}\text { Tranquil } \\
0.37^{*}\end{array}$ & $\begin{array}{l}\text { Crisis } \\
\text { n/a }\end{array}$ & $\begin{array}{c}\text { Tranquil } \\
-0.13^{*}\end{array}$ & $\begin{array}{l}\text { Crisis } \\
\text { n/a }\end{array}$ & $\begin{array}{c}\text { Tranquil } \\
0.17^{*}\end{array}$ & $\begin{array}{l}\text { Crisis } \\
\text { n/a }\end{array}$ & $\begin{array}{c}\text { Tranquil } \\
0.23^{*}\end{array}$ \\
\hline Middle-High Income & $0.56 *$ & $0.36^{*}$ & $0.38 *$ & $0.41 *$ & $-0.41 *$ & $-0.14^{*}$ & $\mathrm{n} / \mathrm{a}$ & $-0.22 *$ \\
\hline Middle-Low Income & $0.57 *$ & $0.28 *$ & 0.05 & $0.24 *$ & -0.15 & $-0.06^{*}$ & $\mathrm{n} / \mathrm{a}$ & 0.08 \\
\hline Low Income & 0.14 & $0.14 *$ & $0.30 *$ & $0.32 *$ & -0.09 & $-0.09 *$ & $\mathrm{n} / \mathrm{a}$ & -0.06 \\
\hline
\end{tabular}

Notes: All correlations were computed using the HP filter.

Pre-1980: Includes observations from 1960 to 1979.

Post-1980: Includes observations from 1980 to 2003.

Fix: Includes years with pegs and crawling pegs.

Flex: Includes years with managed floating and freely floating.

Crisis: Includes years with a 25 percent or higher monthly depreciation that is at least 10 percent higher than the previous month's depreciation as well as the two years following the devaluation.

Tranquil: Includes years not defined as crisis years.

An asterisk denotes statistical significance at the 10 percent level.

Sources: IMF, World Economic Outlook and International Financial Statistics. 
procyclical for the rest of the groups in the post-1980 period. Fourth, monetary policy seems to have switched from acyclical to countercyclical for OECD countries. Lack of data for developing countries precludes a comparison with the earlier period.

\section{b. Fixed versus flexible exchange rates}

Our second partition assesses whether the cyclical patterns in net capital inflows and macroeconomic policies differ across exchange rate regimes (broadly defined). To this effect, we split the sample into three groups (a coarser version of the five-way de facto classification in Reinhart and Rogoff, 2004). The fixed exchange rate group comprises the exchange rate regimes labeled 1 and 2 (pegs and crawling pegs) in the five-way classification just mentioned. The flexible exchange rate group comprises categories 3 (managed floating) and 4 (freely floating). Those labeled "freely falling" by the Reinhart and Rogoff classification (category 5) were excluded from the analysis altogether.

The main results to come out of this exercise are as follows. First, there are no discernible differences in the correlations between net capital inflows and real GDP cycles across the two groups. Second, no differences are detected either for government spending. Third, the inflation tax appears to be more countercyclical for OECD countries and more procyclical for non-OECD countries in flexible regimes. Lastly, monetary policy is more countercyclical for the OECD group under flexible rates.

\section{c. Crisis versus tranquil periods}

We define currency crashes as referring to a 25 percent or higher monthly depreciation that is at least 10 percent higher than the previous month's depreciation. Those years (as well as the two years following the crisis) are treated separately from tranquil periods. The idea is to check whether our main results are driven by the presence of crises. Table 14 suggests that this is definitely not the case. Indeed, our results appear to hold also as strongly - if not more -- in tranquil times. We thus conclude that the paper's message does not depend on our having crises periods in our sample. 


\section{CONCLUDing REMARKS}

We have studied the cyclical properties of capital flows and fiscal and monetary policies for 104 countries for the period 1960-2003. Much more analysis needs to be undertaken to refine our understanding of the links between the business cycle, capital flows, and macroeconomic policies, particularly across such a heterogeneous group of countries and circumstances (and especially in light of endemic data limitations). With these considerations in mind, our main findings can be summarized as follows:

i) Net capital inflows are procyclical in most OECD and developing countries.

ii) Fiscal policy is procyclical for most developing countries and markedly so in middle-high income countries.

iii) Though highly preliminary, we find some evidence of monetary policy procyclicality in developing countries, particularly for the middle-high income countries. There is also some evidence of countercyclical monetary policy for the OECD countries.

iv) For developing countries - and particularly for middle high income countries -- the capital flow cycle and the macroeconomic cycle reinforce each other (the when-it-rains-it pours syndrome).

From a policy point of view, the implications of our findings appear to be of great practical importance. While macroeconomic policies in OECD countries seem to be mostly aimed at stabilizing the business cycle (or, at the very least, remaining neutral), macroeconomic policies in developing countries seem to mostly reinforce the business cycle, turning sunny days into scorching infernos and rainy days into torrential downpours. While there may be a variety of frictions explaining this phenomenon (for instance, political distortions, weak institutions, and capital market imperfections), the inescapable conclusion is that developing countries - and in particular emerging countries - need to find mechanisms that would enable macro-policies to be conducted in a neutral or stabilizing way. In fact, there is some evidence to suggest that emerging countries with a reputation of highly-skilled policymaking (the case of Chile immediately comes to mind) have been able to "graduate" from the 
procyclical gang and conduct neutral/countercyclical fiscal policies (see Calderon and Schmidt-Hebbel (2003)). In the particular case of Chile, the adoption of fiscal rules specifically designed to encourage public saving in good times may have helped in this endeavor.

Finally, it is worth emphasizing that our empirical objective has consisted in computing "reducedform" correlations (in the spirit of the real business cycle literature) and not in identifying policy rules or structural parameters. The types of friction that one would need to introduce into general equilibrium models in order to explain the when-it-rains-it-pours syndrome identified in this paper should be the subject of further research. In sum, we hope that the empirical regularities identified in this paper will stimulate theoreticians to reconsider existing models that may be at odds with the facts and empiricists to revisit the data with more refined techniques. 


\section{REFERENCES}

Aghion, Phillipe, Philippe Bacchetta and Abhijit Banerjee, "Currency Crises and Monetary Policy in an Economy with Credit Constraints,” European Economic Review, Vol. 45 (2001), pp. 1121-1150.

Aizenman, Joshua, Michael Gavin, and Ricardo Hausmann, "Optimal Tax Policy with Endogenous Borrowing Constraints," NBER Working Paper No. 5558 (1996).

Aguiar, Mark, and Gita Gopinath, "Emerging Market Business Cycles: The Cycle is the Trend," mimeo (University of Chicago, 2004).

Baxter, Marianne, and Robert G. King. "Measuring Business Cycles: Approximate Band-Pass Filters for Economic Time Series.” Review of Economics and Statistics 81 (1999): 575-93.

Braun, Miguel, "Why Is Fiscal Policy Procyclical in Developing Countries" (mimeo, Harvard University, 2001).

Calderon, Cesar and Klaus Schmidt-Hebbel, "Macroeconomic Policies and Performance in Latin America," Journal of International Money and Finance, Vol. 22 (2003), pp. 895-923.

Calvo, Guillermo A. "On the Costs of Temporary Policy," Journal of Development Economics, Vol. 27 (1987), pp. 245-262.

Calvo, Guillermo A., Leonardo Leiderman, and Carmen M. Reinhart, "Capital Inflows and Real Exchange Rate Appreciation in Latin America: The Role of External Factors," IMF Staff Papers, Vol. 40 (1993), pp. 108-151.

Calvo, Guillermo A., Leonardo Leiderman, and Carmen M. Reinhart, "The Capital Inflows Problem: Concepts and Issues," Contemporary Economic Policy, Vol. XII (1994), pp. 54-66.

Calvo, Guillermo A. and Carlos A. Végh, "Inflation Stabilization and BOP Crises in Developing Countries" in John Taylor and Michael Woodford, eds., Handbook of Macroeconomics (Volume C; North Holland, 1999), pp. 1531-1614.

Chari, V.V. and Patrick Kehoe, "Optimal Fiscal and Monetary Policy,” NBER Working Papers No. 6891 (1999).

Clarida, Richard, Jordi Gali, and Mark Gertler, "Monetary Policy Rules in Practice: Some International Evidence," NBER Working Paper No. 6254 (1997).

Clarida, Richard, Jordi Gali, and Mark Gertler, "The Science of Monetary Policy; A New Keynesian Perspective," Journal of Economic Literature, Vol. 37 (1999), pp. 1161-1707.

Corbo, Vittorio, "Monetary Policy in Latin America in the 90s," Central Bank of Chile Working Paper No. 78 (2000).

Cuddington, John, "Commodity Export Booms in Developing Countries" The World Bank Research Observer, Vol. 4, No. 2, July 1989, 143-165.

Dixon, Jay, "Voracity, Volatility, and Growth" (mimeo, UCLA, 2003). 
Drazen, Alan, "Interest Rate and Borrowing Defense Against Speculative Attack," Carnegie-Rochester Series on Public Policy, Vol. 53 (2000).

Flood, Robert P. and Olivier Jeanne, “An Interest Rate Defense of a Fixed Exchange Rate?" IMF Working Paper No. 00/159 (2000).

Gavin, Michael, and Roberto Perotti, "Fiscal Policy in Latin America," NBER Macroeconomics Annual (Cambridge, Mass.: MIT Press, 1997), pp. 11-61.

Gupta, Sanjeev, Benedict Clements, Bernardin Akitoby, and Gabriela Inchauste, "The Cyclicality of Government Spending in Developing Countries" (mimeo, IMF, 2004).

Lahiri, Amartya and Carlos A. Végh, "Delaying the Inevitable: Interest Rate Defense and BOP Crises," Journal of Political Economy, Vol. 111 (2003), pp. 404-424.

Lahiri, Amartya and Carlos A. Végh, "On the Non-Monotonic Relation between Interest Rates and the Exchange Rate," mimeo (New York Fed and UCLA, 2004).

Lane, Philip, "The Cyclical Behavior of Fiscal Policy: Evidence from the OECD" Journal of Public Economics, Vol. 87 (2003a), pp. 2661-2675.

Lane, Philip, "Business Cycles and Macroeconomic Policy in Emerging Market Economies" (mimeo, Trinity College, Dublin, 2003b).

Lane, Philip and Aaron Tornell, "Why Aren't Latin American Savings Rates Procyclical? Journal of Development Economics, Vol. 57 (1998), pp. 185-200.

Moron, Eduardo and Juan Francisco Castro, 2000, "Uncovering Central Bank's Monetary Policy Objective: Going Beyond the Fear of Floating," (mimeo, Universidad del Pacifico).

Neumeyer, Pablo A., and Fabrizio Perri, "Business Cycles in Emerging Economies: The Role of Interest Rates,” NBER Working Paper No. 10837 (2004).

Pallage, Stephane, and Michel A. Robe, "Foreign Aid and the Business Cycle," Review of International Economics, Vol. 9 (2001), pp. 637-668.

Phelps, Edmund (1973), "Inflation in the Theory of Public Finance," Swedish Journal of Economics, Vol. (75), pp. 67-82.

Reinhart, Carmen M. and Kenneth S. Rogoff. "The Modern History of Exchange Rate Arrangements: A Reinterpretation.” Quarterly Journal of Economics, Vol. CXIX No. 1, February 2004, 1-48

Reinhart, Carmen M., Kenneth S. Rogoff, and Miguel A. Savastano. "Debt Intolerance," in William Brainard and George Perry, eds., Brookings Papers on Economic Activity, Vol.1 Spring 2003, 174.

Riascos, Alvaro and Carlos A. Végh, "Procyclical Fiscal Policy in Developing Countries: The Role of Incomplete Markets" (mimeo, UCLA and Banco Republica, Colombia, 2003). 
Talvi, Ernesto, and Carlos A. Végh, "Tax Base Variability and Procyclical Fiscal Policy," NBER Working Paper No. 7499 (2000), forthcoming Journal of Development Economics.

Taylor, John, "Discretion versus Policy Rules in Practice," Carnegie-Rochester Conference Series on Public Policy, Vol. 39 (1993), pp. 195-214.

Tornell, Aaron and Philip Lane, "The Voracity Effect," American Economic Review, Vol. 89 (1999), pp. $22-46$.

World Bank, various issues. Global Development Finance. (Washington DC: The World Bank). 


\section{APPENDIX. INDEX OF CYCLICALITY OF FISCAL POLICY}

This paper has explored the cyclical properties of a variety of fiscal policy indicators. We now construct a summary measure of the cyclical properties of fiscal policy. This composite index could be used to rank individual countries in terms of their fiscal policy stance and, in future empirical work, to explain this cross-country variation using a variety of economic, political, and institutional variables. While the selection of both the components of the composite index and the weights attached to them is necessarily arbitrary, the indicators were selected on the basis that they provide an unambiguous reading of the stance of policy. The composite fiscal policy index, denoted by $c_{f}$, is constructed as follows (see Appendix Table 5):

$c_{f}=0.40 \rho_{g}+0.40$ Percentile $\left\{a_{g}-b_{g}\right\}-0.20 \rho_{\pi}$,

where $\rho_{g}$ is the (HP) correlation between the cyclical components of real GDP and central government expenditure, $a_{g}$ is the average growth in central government expenditure when GDP is above the median, $b_{g}$ is the average growth in central government expenditure when GDP is below the median (as shown in Table 9), and $\rho_{\pi}$ is the (HP) correlation between real GDP and the inflation tax, $\pi /(1+\pi)$ (as shown in Table 9). Thus, $a_{g}-b_{g}$ provides a measure of the amplitude of the fiscal spending cycle that correlations do not reveal. To normalize this measure of amplitude - so that it lies in the interval between minus one and one and is thus in the same units as the correlations - we distribute positive and negative observations into percentiles and then assign that particular percentile to the country. For instance, as revealed by Appendix Table 5, Argentina has an amplitude of 5.35 percentage points (i.e., the growth rate of government spending is 5.35 percentage points higher in good times than in bad times). This observation corresponds to the $17^{\text {th }}$ percentile of all positive observations. We thus assign Argentina the value of 0.17 .

The first two components are given a higher weight (0.40) in the composite, as many countries in our sample (both developed and developing) did not rely as heavily on the inflation tax, which is assigned 
a weight of 0.20 . Hence, since each component of the index, $c_{f}$, is confined to values between one and minus one, so is the index, with 1 being most procyclical and -1 most countercyclical. 
Figure 1

Country Correlations between

the Cyclical Components of Net Capital Inflows and Real GDP

1960-2003

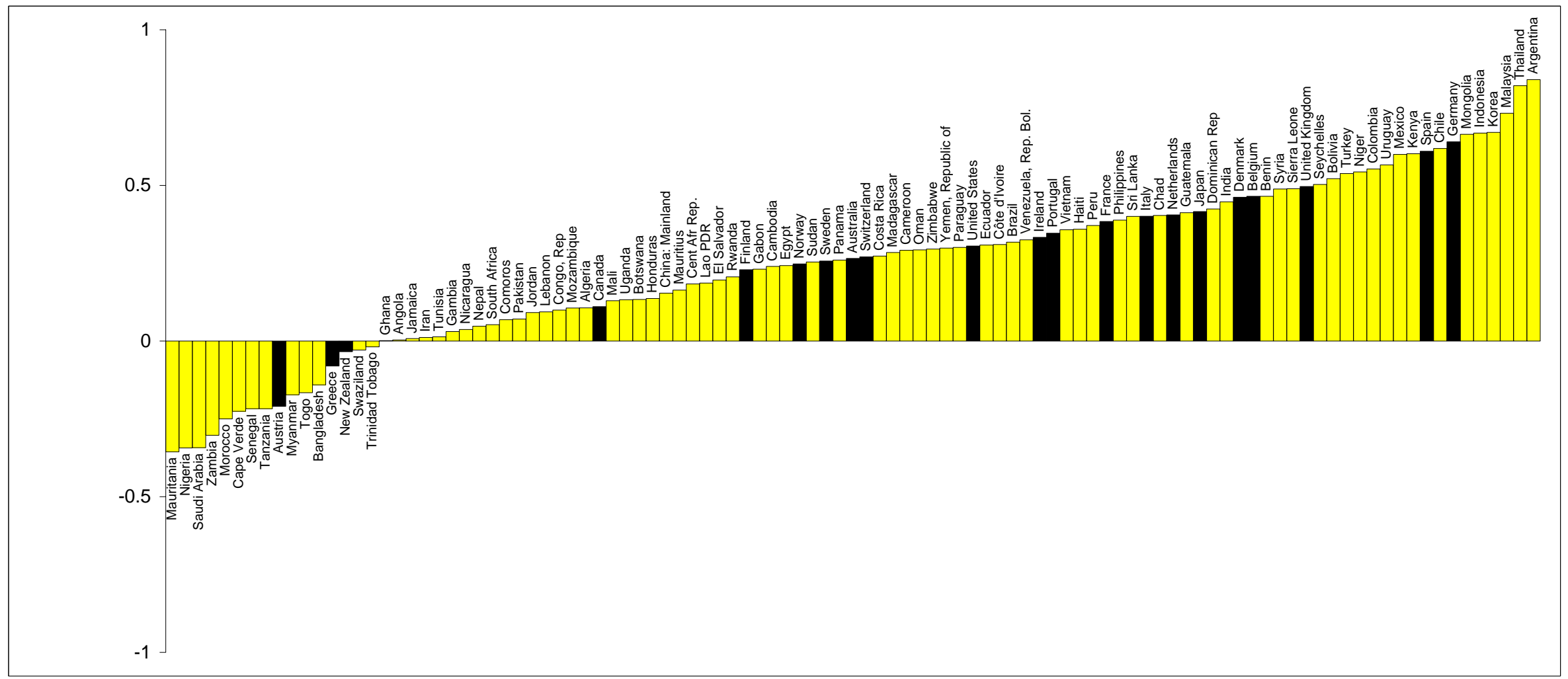

Notes: Dark bars are OECD countries and light ones are non-OECD countries. The cyclical components have been estimated using the Hodrick-Prescott Filter. A positive correlation indicates procyclical capital flows.

Source: IMF, World Economic Outlook. 
Figure 2

Country Correlations between

the Cyclical Components of Real Government Expenditure and Real GDP 1960-2003

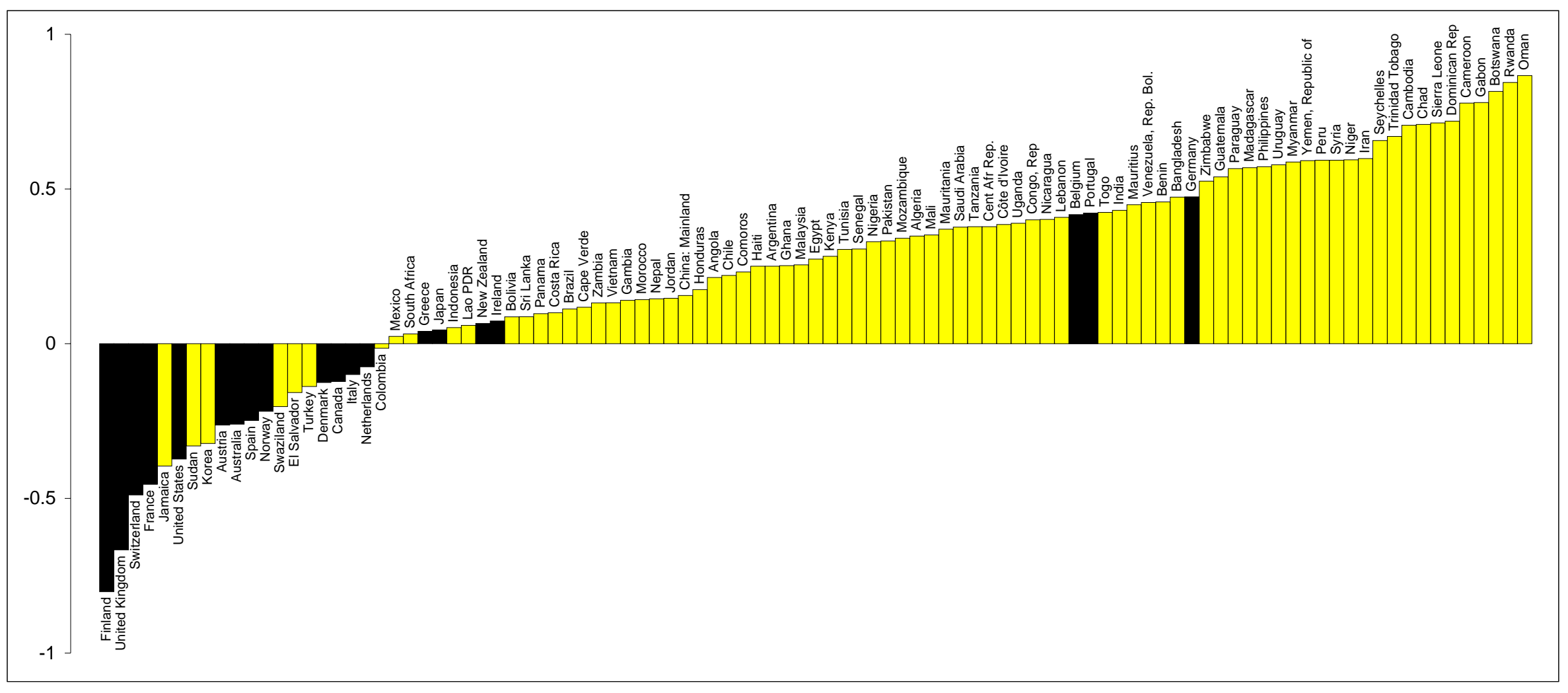

Notes: Dark bars are OECD countries and light ones are non-OECD countries. The cyclical components have been estimated using the Hodrick-Prescott Filter.

A positive correlation indicates procyclical fiscal policy. Real government expenditure is defined as Central Government expenditure deflated by the GDP deflator.

Source: IMF, World Economic Outlook. 
Figure 3

Amplitude of the Fiscal Policy Cycle

1960-2003

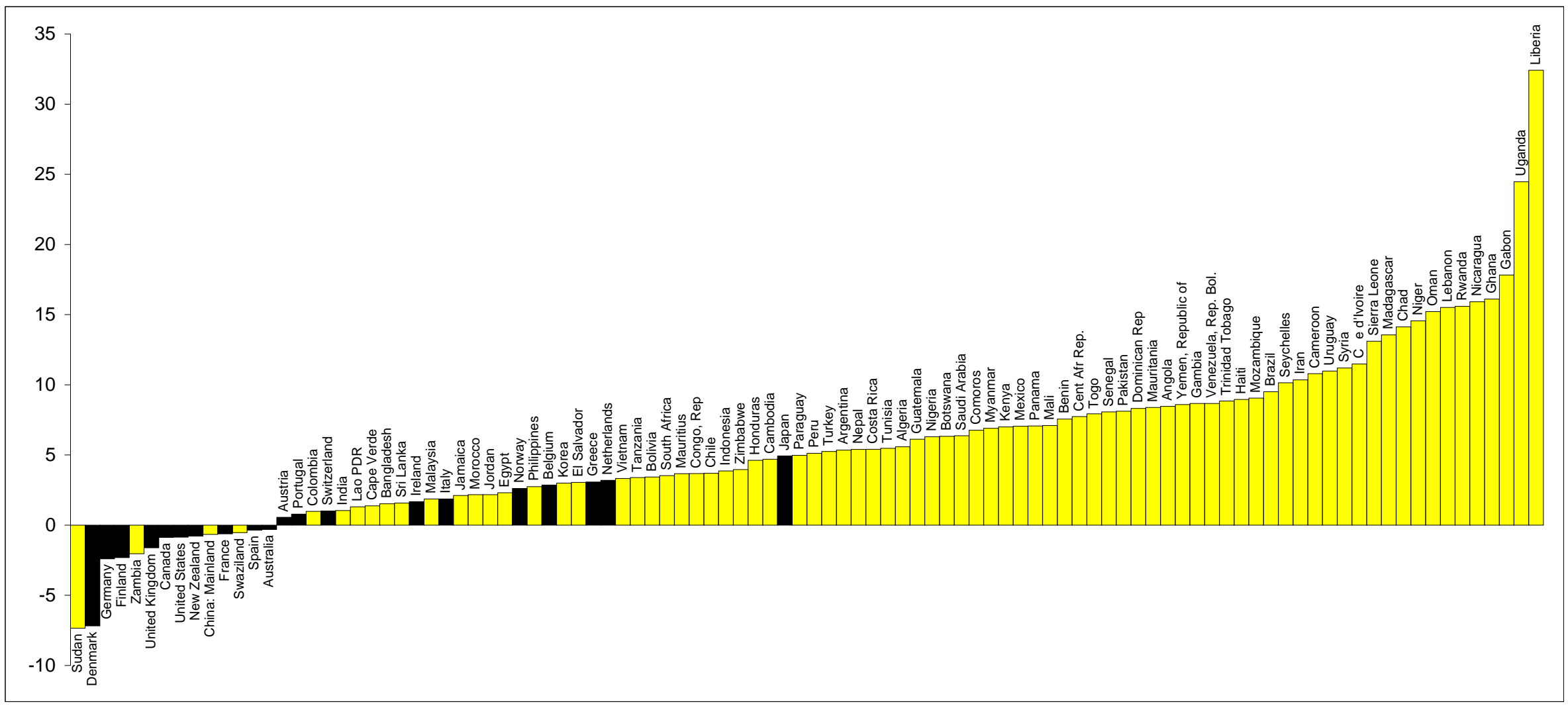

Notes: Dark bars are OECD countries and light ones are non-OECD countries. The amplitude of the fiscal policy cycle is captured by the difference (in percentage points)

between the growth of real government expenditure in good times and bad times. Real government expenditure is defined as Central Government expenditure deflated by the GDP deflator. Good (bad) times are defined as those years in which GDP growth is above (below) the median. A positive amplitude indicates procyclical fiscal policy.

Source: IMF, World Economic Outlook. 
Figure 4

Country Correlations between

the Cyclical Components of the Inflation Tax and Real GDP 1960-2003

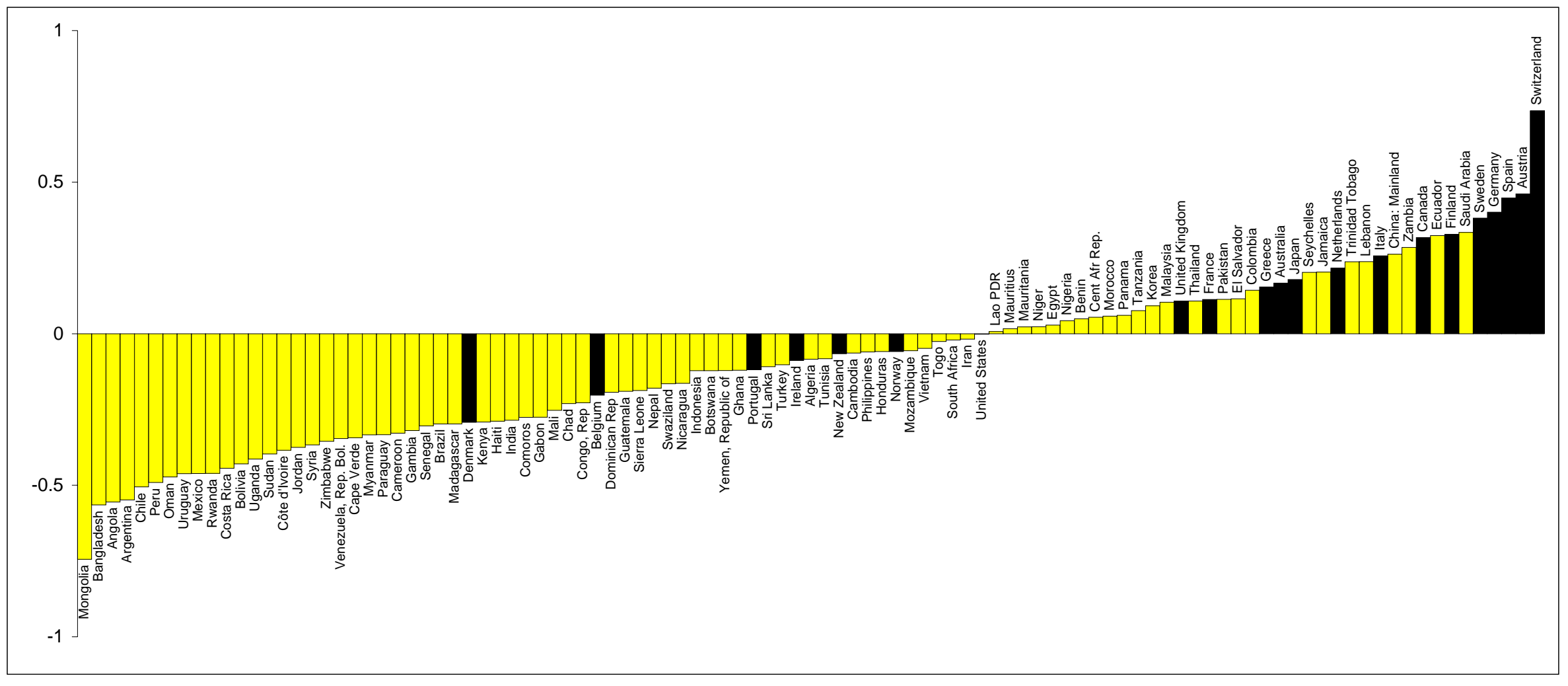

Notes: Dark bars are OECD countries and light ones are non-OECD countries. The cyclical components have been estimated using the Hodrick-Prescott Filter. A positive correlation indicates countercyclical fiscal policy.

Sources: IMF, World Economic Outlook and International Financial Statistics. 
Figure 5

Country Correlations between

the Cyclical Components of the Nominal Lending Interest Rate and Real GDP 1960-2003

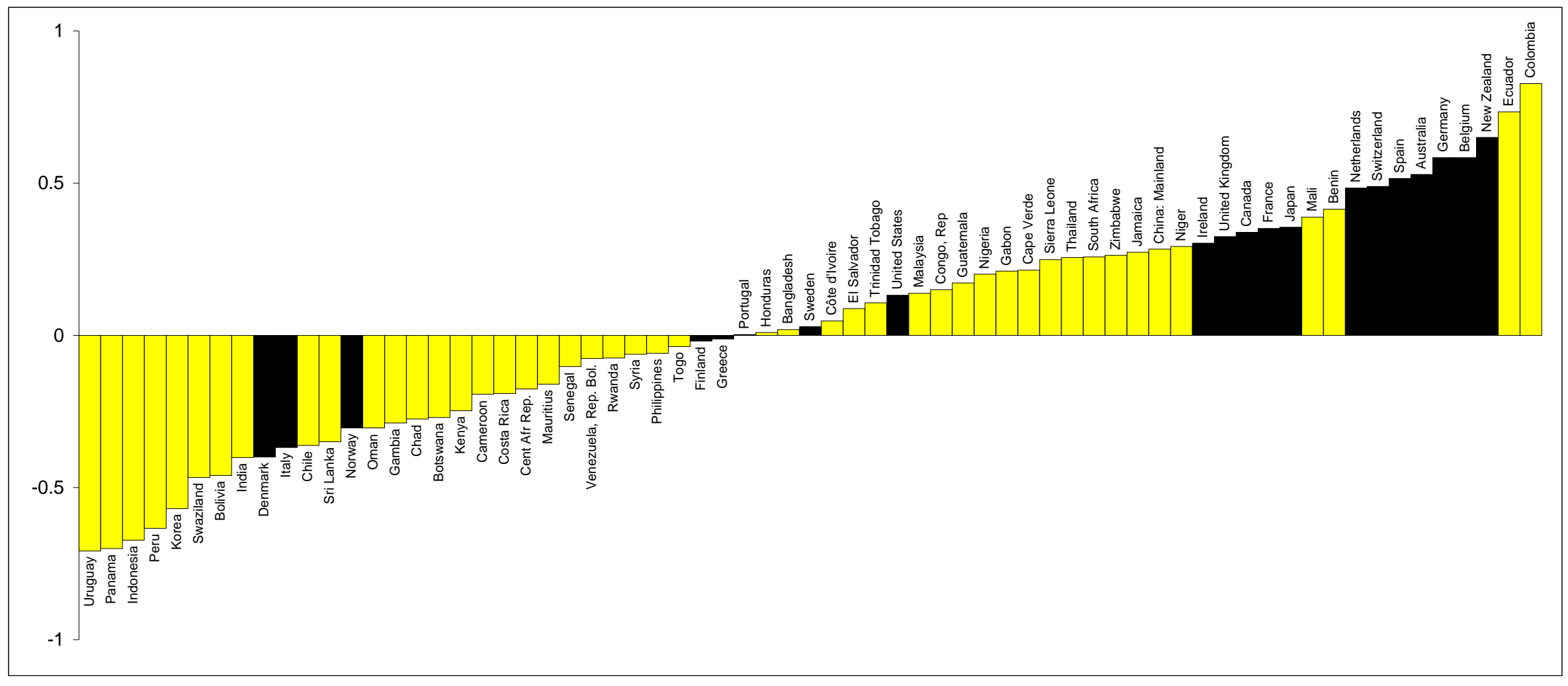

Notes: Dark bars are OECD countries and light ones are non-OECD countries. The cyclical components have been estimated using the Hodrick-Prescott Filter.

A positive correlation indicates countercyclical monetary policy.

Sources: IMF, World Economic Outlook and International Financial Statistics . 
Figure 6

Country Correlations between the Cyclical Components

of Real Government Expenditure and Net Capital Inflows

1960-2003

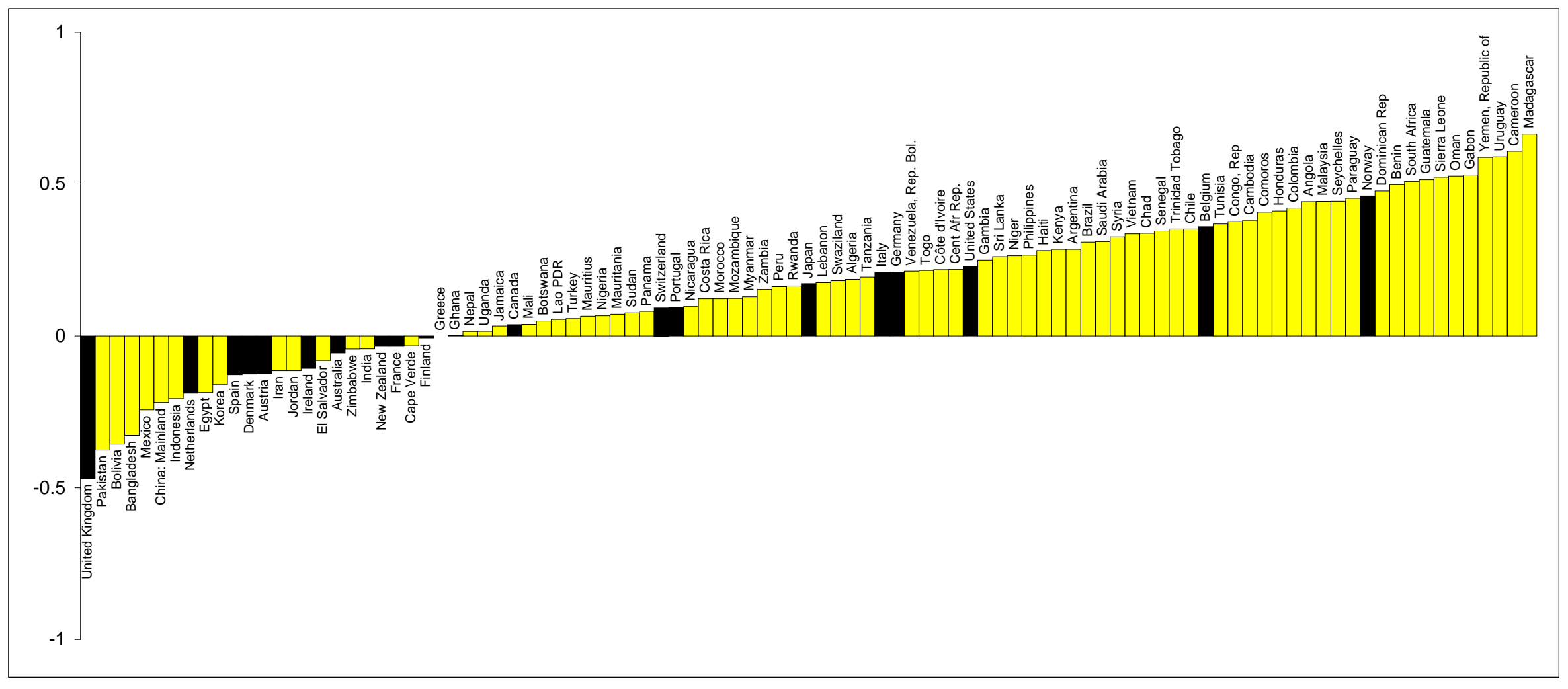

Notes: Dark bars are OECD countries and light ones are non-OECD countries. The cyclical components have been estimated using the Hodrick-Prescott Filter. Real government expenditure is defined as Central Government expenditure deflated by the GDP deflator.

Source: IMF, World Economic Outlook. 
Figure 7

Country Correlations between the Cyclical Components

of the Inflation Tax and Net Capital Inflows

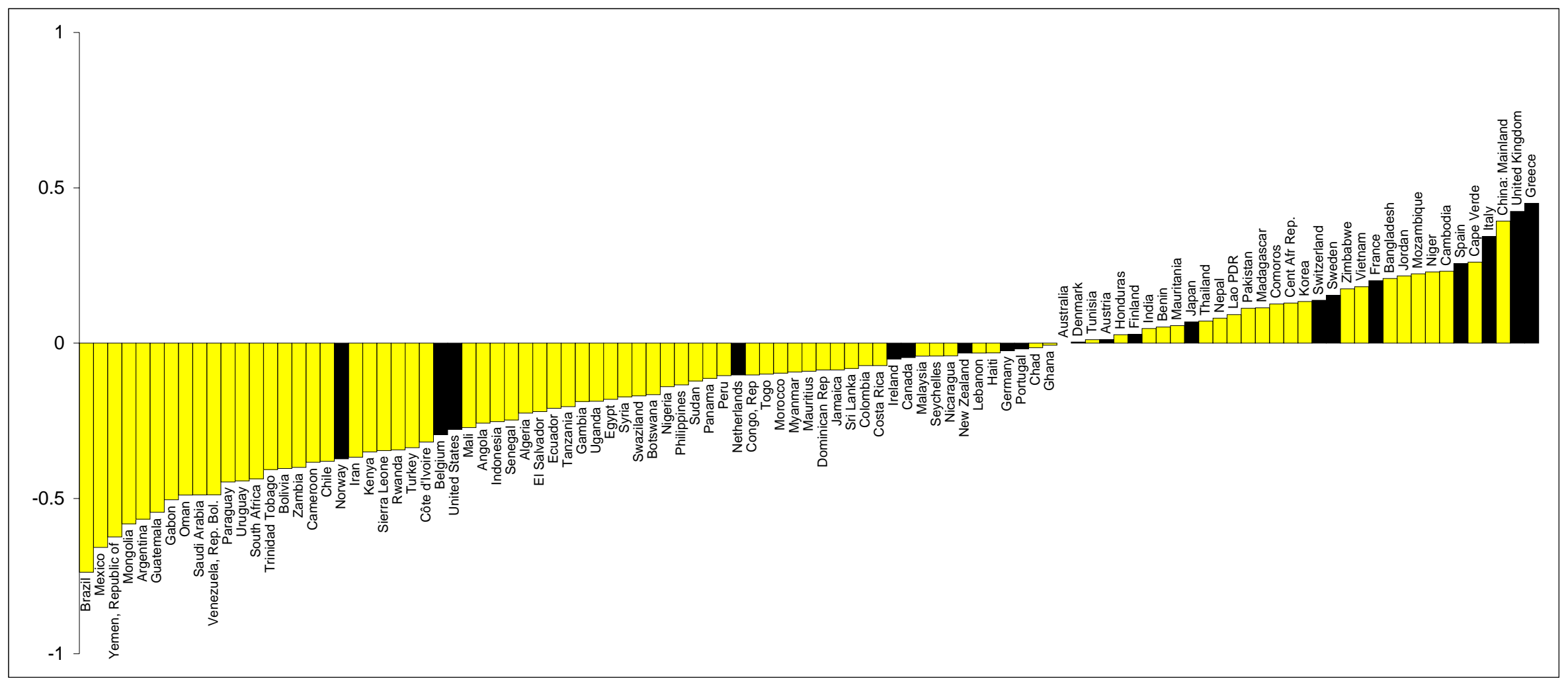

Notes: Dark bars are OECD countries and light ones are non-OECD countries. The cyclical components have been estimated using the Hodrick-Prescott Filter. Source: IMF, World Economic Outlook. 
Figure 8

Country Correlations between the Cyclical Components of the Nominal Lending Interest Rate and Net Capital Inflows 1960-2003

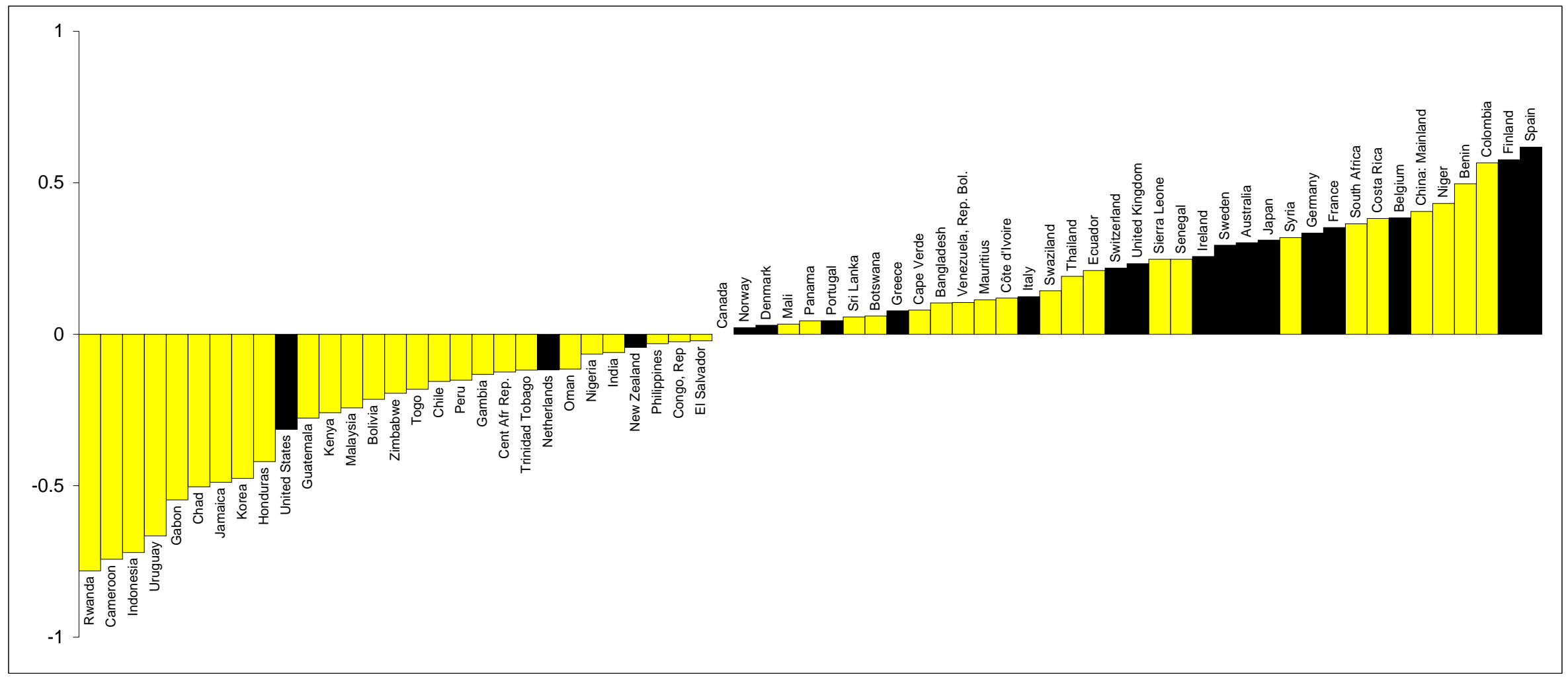

Notes: Dark bars are OECD countries and light ones are non-OECD countries. The cyclical components have been estimated using the Hodrick-Prescott Filter. Source: IMF, World Economic Outlook. 
Appendix Table 1

Data Sources

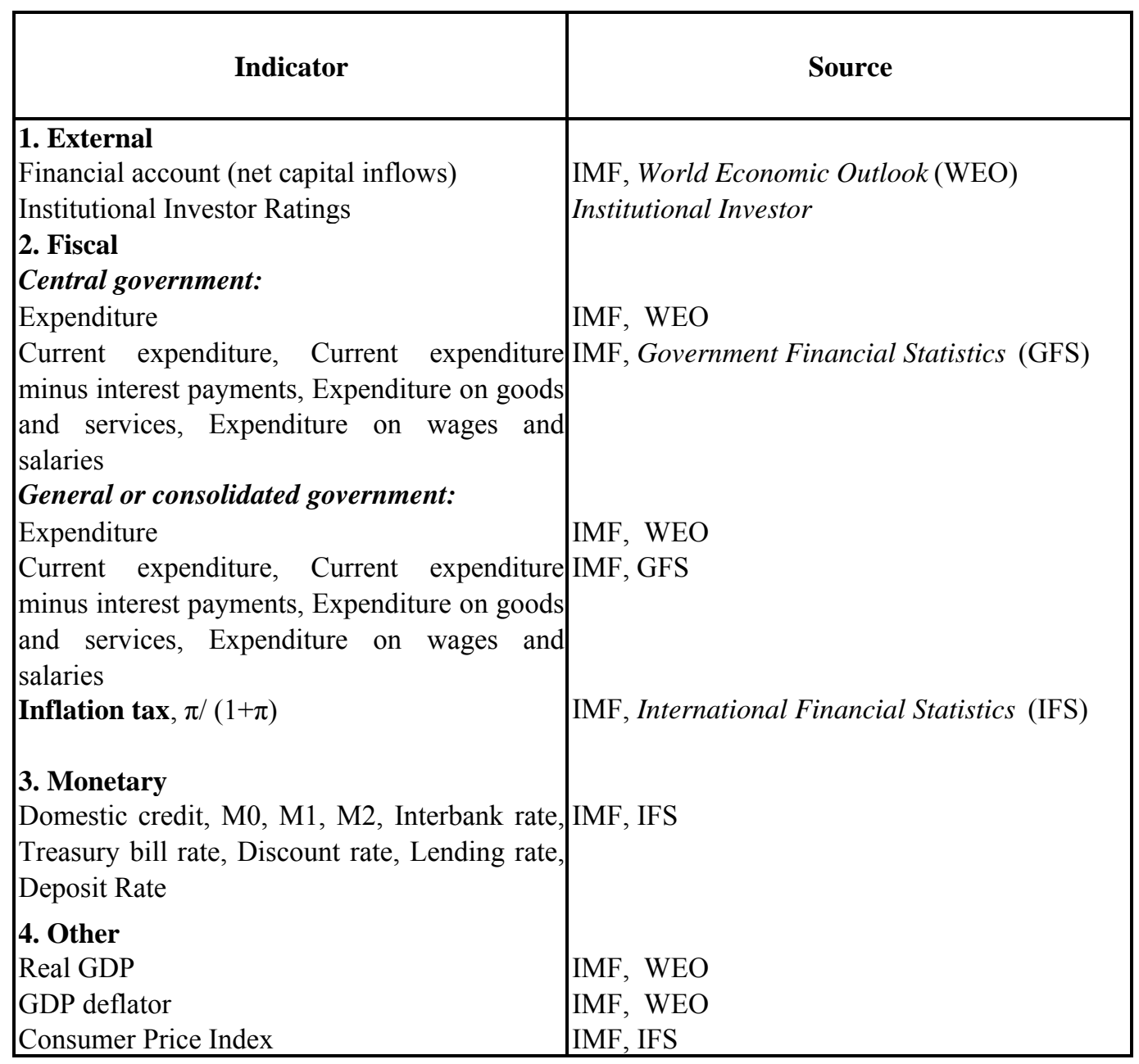

Note: WEO uses the concept of Central and General government expenditure, while GFS uses Central Government Budgetary Accounts and Consolidated Government Accounts. 
Appendix Table 2

Countries in the Sample

\begin{tabular}{|c|c|c|c|}
\hline $\begin{array}{c}\text { Low-Income Countries } \\
(40)\end{array}$ & $\begin{array}{l}\text { Middle-Low Income } \\
\text { Countries (25) } \\
\end{array}$ & $\begin{array}{l}\text { Middle-High Income } \\
\text { Countries (18) }\end{array}$ & $\begin{array}{c}\text { OECD Countries } \\
(21) \\
\end{array}$ \\
\hline $\begin{array}{l}\text { Angola } \\
\text { Bangladesh } \\
\text { Benin } \\
\text { Burma (now Myanmar) } \\
\text { Cambodia } \\
\text { Cameroon } \\
\text { Central African Republic } \\
\text { Chad } \\
\text { Comoros } \\
\text { Congo (Republic of) } \\
\text { Côte D’Ivoire } \\
\text { The Gambia } \\
\text { Ghana } \\
\text { Haiti } \\
\text { India } \\
\text { Indonesia } \\
\text { Kenya } \\
\text { Laos } \\
\text { Liberia } \\
\text { Madagascar } \\
\text { Mali } \\
\text { Mauritania } \\
\text { Mongolia } \\
\text { Mozambique } \\
\text { Nepal } \\
\text { Nicaragua } \\
\text { Niger } \\
\text { Nigeria } \\
\text { Pakistan } \\
\text { Rwanda } \\
\text { Senegal } \\
\text { Sierra Leone } \\
\text { Sudan } \\
\text { Tanzania } \\
\text { Togo } \\
\text { Uganda } \\
\text { Vietnam } \\
\text { Yemen } \\
\text { Zambia } \\
\text { Zimbabwe }\end{array}$ & $\begin{array}{l}\text { Algeria } \\
\text { Bolivia } \\
\text { Cape Verde } \\
\text { China } \\
\text { Colombia } \\
\text { Dominican Republic } \\
\text { Ecuador } \\
\text { Egypt } \\
\text { El Salvador } \\
\text { Guatemala } \\
\text { Honduras } \\
\text { Iran } \\
\text { Iraq } \\
\text { Jamaica } \\
\text { Jordan } \\
\text { Morocco } \\
\text { Paraguay } \\
\text { Peru } \\
\text { Philippines } \\
\text { South Africa } \\
\text { Sri Lanka } \\
\text { Syria } \\
\text { Thailand } \\
\text { Tunisia } \\
\text { Turkey }\end{array}$ & $\begin{array}{l}\text { Argentina } \\
\text { Botswana } \\
\text { Brazil } \\
\text { Chile } \\
\text { Costa Rica } \\
\text { Gabon } \\
\text { Korea, Rep. of } \\
\text { Lebanon } \\
\text { Malaysia } \\
\text { Mauritius } \\
\text { Mexico } \\
\text { Oman } \\
\text { Panama } \\
\text { Saudi Arabia } \\
\text { Seychelles } \\
\text { Trinidad and Tobago } \\
\text { Uruguay } \\
\text { Venezuela }\end{array}$ & $\begin{array}{l}\text { Australia } \\
\text { Austria } \\
\text { Belgium } \\
\text { Canada } \\
\text { Denmark } \\
\text { Finland } \\
\text { France } \\
\text { Germany } \\
\text { Greece } \\
\text { Japan } \\
\text { Ireland } \\
\text { Italy } \\
\text { Netherlands } \\
\text { New Zealand } \\
\text { Norway } \\
\text { Portugal } \\
\text { Spain } \\
\text { Sweden } \\
\text { Switzerland } \\
\text { United Kingdom } \\
\text { United States }\end{array}$ \\
\hline
\end{tabular}

Note: The total number of countries is 104.

Iceland and Luxembourg are not included in our sample of OECD countries and Korea is included in the middle-high income countries. 
Appendix Table 3

Amplitude of the Real Interest Rate Cycle

\begin{tabular}{|c|c|c|c|}
\hline \multirow{2}{*}{$\begin{array}{c}\text { Real } \\
\text { Interest Rate }\end{array}$} & \multicolumn{3}{|c|}{ Increases in Real Interest Rates } \\
\hline & $\begin{array}{c}\text { Good Times } \\
\text { (1) } \\
\end{array}$ & $\begin{array}{c}\text { Bad Times } \\
\text { (2) }\end{array}$ & $\begin{array}{c}\text { Amplitude } \\
\text { (1)-(2) } \\
\end{array}$ \\
\hline \multicolumn{4}{|c|}{ OECD } \\
\hline Interbank rate & 0.1 & -0.2 & 0.3 \\
\hline Treasury bill rate & 0.4 & -0.2 & 0.6 \\
\hline Discount rate & 0.3 & -0.4 & 0.7 \\
\hline Lending rate & -0.1 & 0.1 & -0.2 \\
\hline Deposit rate & 0.0 & 0.0 & 0.0 \\
\hline \multicolumn{4}{|c|}{ Middle-High Income Countries } \\
\hline Interbank rate * & 2.2 & 3.1 & -0.9 \\
\hline Treasury bill rate & -2.8 & 1.6 & -4.4 \\
\hline Discount rate & -1.0 & 2.6 & -3.6 \\
\hline Lending rate & -2.5 & 1.7 & -4.2 \\
\hline Deposit rate * & 1.1 & 0.8 & 0.3 \\
\hline \multicolumn{4}{|c|}{ Middle-Low Income Countries } \\
\hline Interbank rate & -0.4 & 0.4 & -0.8 \\
\hline Treasury bill rate & -0.6 & 1.1 & -1.7 \\
\hline Discount rate & 0.4 & -0.4 & 0.8 \\
\hline Lending rate* & -0.6 & 1.0 & -1.6 \\
\hline Deposit rate* & -0.4 & -0.1 & -0.3 \\
\hline \multicolumn{4}{|c|}{ Low Income Countries } \\
\hline Interbank rate & 1.3 & 0.1 & 1.2 \\
\hline Treasury bill rate & 4.8 & -0.9 & 5.7 \\
\hline Discount rate* & 1.1 & -2.3 & 3.4 \\
\hline Lending rate* & -1.4 & -0.2 & -1.2 \\
\hline Deposit rate* & 0.4 & -1.0 & 1.4 \\
\hline
\end{tabular}

Notes: Increases in real interest rates are defined as the average annual change in real interest rates (with real interest rates expressed in percentage points)

Good (bad) times are defined as those years with GDP growth above (below) the median.

* The median is reported in lieu of the average, as the average is distorted by or more very high inflation (or hyperinflation) episodes.

Sources: IMF, World Economic Outlook and International Financial Statistic 


\section{Appendix Table 4 \\ Amplitude of the Real Monetary Aggregate Cycle}

\begin{tabular}{|c|c|c|c|}
\hline \multirow{2}{*}{$\begin{array}{c}\text { Real } \\
\text { Monetary } \\
\text { Aggregates }\end{array}$} & \multicolumn{3}{|c|}{ Increases in Real Monetary Aggregates } \\
\hline & $\begin{array}{c}\text { Good Times } \\
\text { (1) }\end{array}$ & $\begin{array}{c}\text { Bad Times } \\
\text { (2) }\end{array}$ & $\begin{array}{l}\text { Amplitude } \\
\text { (1)-(2) }\end{array}$ \\
\hline \multicolumn{4}{|c|}{ OECD Countries } \\
\hline M0 & 3.2 & 0.8 & 2.4 \\
\hline M1 & 5.4 & 4.0 & 1.4 \\
\hline M2 & 6.6 & 3.3 & 3.3 \\
\hline \multicolumn{4}{|c|}{ Middle-High Income Countries } \\
\hline M0 & 7.7 & 3.0 & 4.7 \\
\hline M1 & 8.3 & 1.0 & 7.3 \\
\hline M2 & 11.5 & 3.3 & 8.2 \\
\hline \multicolumn{4}{|c|}{ Middle-Low Income Countries } \\
\hline M0 & 6.2 & 2.4 & 3.8 \\
\hline M1 & 5.9 & 2.4 & 3.5 \\
\hline M2 & 8.2 & 4.5 & 3.7 \\
\hline \multicolumn{4}{|c|}{ Low Income Countries } \\
\hline M0 & 4.3 & 0.8 & 3.5 \\
\hline M1 & 3.2 & 0.9 & 2.3 \\
\hline M2 & 6.7 & 1.4 & 5.3 \\
\hline
\end{tabular}

Notes: The increase in real monetary aggregates is the average annual real rate of growth expressed in percentage terms. Good (bad) times are defined as those years with GDP growth above (below) the median.

Sources: IMF, International Financial Statistics. 
Appendix Table 5
Index of Cyclicality of Fiscal Policy

\begin{tabular}{|c|c|c|c|c|c|c|c|c|c|c|c|}
\hline \multirow[t]{2}{*}{ Countries } & \multicolumn{2}{|c|}{$\begin{array}{l}\text { Correlations between the Cyclical } \\
\text { Components of Real GDP and }\end{array}$} & \multicolumn{2}{|c|}{$\begin{array}{l}\text { Amplitude of the Cycle of } \\
\text { Central Government Expenditure }\end{array}$} & \multirow{2}{*}{$\begin{array}{c}\text { Index of Cyclicality } \\
\text { of } \\
\text { Fiscal Policy } \\
0.4^{*}(1)+0.4^{*}(4)-0.2^{*}(4) \\
\end{array}$} & \multirow[t]{2}{*}{ Countries } & \multicolumn{2}{|c|}{$\begin{array}{l}\text { Correlations between the Cyclical } \\
\text { Components of Real GDP and }\end{array}$} & \multicolumn{2}{|c|}{$\begin{array}{l}\text { Amplitude of the Cycle of } \\
\text { Central Government Expenditure }\end{array}$} & \multirow{2}{*}{$\begin{array}{c}\begin{array}{c}\text { Index of Cyclicality } \\
\text { of } \\
\text { Fiscal Policy }\end{array} \\
0.4^{*}(1)+0.4^{*}(4)-0.2^{*}(4)\end{array}$} \\
\hline & \begin{tabular}{|c|}
$\begin{array}{c}\text { Real Central } \\
\text { Government Expenditure } \\
\text { (1) }\end{array}$ \\
\end{tabular} & $\begin{array}{l}\text { Inflation Tax } \\
\text { (2) } \\
\end{array}$ & $\begin{array}{c}\text { Level } \\
\text { (Percentage Points) } \\
\text { (3) }\end{array}$ & $\begin{array}{c}\text { Percentiles } \\
\text { (4) }\end{array}$ & & & \begin{tabular}{|c|}
$\begin{array}{c}\text { Real Central } \\
\text { Government Expenditure } \\
\text { (1) }\end{array}$ \\
\end{tabular} & $\begin{array}{c}\text { Inflation Tax } \\
\text { (2) } \\
\end{array}$ & $\begin{array}{c}\text { Level } \\
\text { (Percentage Points) } \\
\text { (3) }\end{array}$ & $\begin{array}{c}\text { Percentiles } \\
\text { (4) }\end{array}$ & \\
\hline Algeria & 0.35 & -0.08 & & & & Madagascar & & & & & \\
\hline Angola & 0.21 & -0.56 & 8.46 & 0.27 & 0.30 & Malaysia & 0.25 & 0.10 & 1.86 & 0.06 & 0.11 \\
\hline Argentina & 0.25 & -0.55 & 5.35 & 0.17 & 0.28 & Mali & 0.35 & -0.25 & 7.10 & 0.22 & 0.28 \\
\hline Australia & -0.26 & 0.17 & -0.31 & -0.04 & -0.15 & Mauritania & 0.37 & 0.02 & 8.39 & 0.26 & 0.25 \\
\hline Austria & -0.26 & 0.46 & 0.56 & 0.02 & -0.19 & Mauritius & 0.45 & 0.02 & 3.66 & 0.12 & 0.22 \\
\hline Bangladesh & 0.47 & -0.57 & 1.53 & 0.05 & 0.32 & Mexico & 0.02 & -0.46 & 7.05 & 0.22 & 0.19 \\
\hline | Belgium & 0.42 & -0.20 & 2.86 & 0.09 & 0.24 & Mongolia & na & -0.74 & na & na & na \\
\hline Benin & 0.46 & 0.05 & 7.56 & 0.24 & 0.27 & Morocco & 0.14 & 0.06 & 2.17 & 0.07 & 0.07 \\
\hline Bolivia & 0.09 & -0.43 & 3.43 & 0.11 & 0.16 & Mozambique & 0.34 & -0.06 & 9.05 & 0.28 & 0.26 \\
\hline $\mid$\begin{tabular}{|l} 
Botswana \\
Brazil
\end{tabular} & $\begin{array}{l}0.82 \\
0.11\end{array}$ & $\begin{array}{l}-0.12 \\
-0.30\end{array}$ & $\begin{array}{l}6.333 \\
9.50\end{array}$ & $\begin{array}{l}0.20 \\
0.30\end{array}$ & $\begin{array}{l}0.43 \\
0.22\end{array}$ & $\mid \begin{array}{l}\text { Myanmar } \\
\text { Nepal }\end{array}$ & $\begin{array}{l}0.59 \\
0.14\end{array}$ & $\begin{array}{l}-0.33 \\
-0.18\end{array}$ & $\begin{array}{l}6.90 \\
5.40\end{array}$ & $\begin{array}{l}0.22 \\
0.17\end{array}$ & $\begin{array}{l}0.39 \\
0.16\end{array}$ \\
\hline Cambodia & 0.71 & $\begin{array}{l}-0.06 \\
-0.06 \\
-100\end{array}$ & 4.70 & 0.15 & 0.36 & $\begin{array}{l}\text { Netherlands } \\
\text { Nepid }\end{array}$ & $\begin{array}{l}-.14 \\
-0.07\end{array}$ & 0.22 & $\begin{array}{l}3.40 \\
3.19\end{array}$ & 0.10 & $\begin{array}{l}0.03 \\
-0.03\end{array}$ \\
\hline Cameroon & 0.78 & -0.33 & 10.79 & 0.34 & 0.51 & New Zealand & 0.07 & $\begin{array}{l}-0.07 \\
-0.22\end{array}$ & $\begin{array}{l}-0.77 \\
-1.77\end{array}$ & -0.10 & 0.00 \\
\hline Canada & -0.12 & 0.32 & -0.88 & -0.11 & -0.16 & $\begin{array}{l}\text { Nicaragua } \\
\text { Pa }\end{array}$ & 0.40 & -0.16 & 15.92 & 0.50 & 0.39 \\
\hline Cape Verde & 0.12 & -0.34 & 1.38 & 0.05 & 0.14 & Niger & 0.59 & 0.02 & 14.56 & 0.45 & 0.41 \\
\hline Cent Afr Rep. & 0.38 & 0.05 & 7.73 & 0.24 & 0.24 & Nigeria & 0.33 & 0.04 & 6.30 & 0.20 & 0.20 \\
\hline Chad & 0.71 & -0.23 & 14.12 & 0.44 & 0.51 & Norway & -0.22 & -0.06 & 2.61 & 0.09 & -0.04 \\
\hline Chile & 0.22 & -0.51 & 3.69 & 0.12 & 0.24 & Oman & 0.87 & -0.47 & 15.22 & 0.47 & 0.63 \\
\hline China: Mainland & 0.16 & 0.26 & -0.66 & -0.09 & -0.03 & Pakistan & 0.33 & 0.11 & 8.12 & 0.26 & 0.21 \\
\hline Colombia & -0.01 & 0.14 & 0.99 & 0.04 & -0.02 & Panama & 0.10 & 0.06 & 7.06 & 0.22 & 0.11 \\
\hline Comoros & 0.23 & -0.28 & 6.76 & 0.21 & 0.23 & Paraguay & 0.57 & -0.33 & 4.97 & 0.16 & 0.36 \\
\hline Congo, Rep & & -0.23 & 3.67 & 0.12 & 0.25 & Peru & 0.59 & -0.49 & 5.12 & 0.16 & 0.40 \\
\hline Costa Rica & 0.10 & -0.44 & 5.41 & 0.17 & 0.20 & Philippines & 0.57 & -0.06 & 2.74 & 0.09 & 0.28 \\
\hline Cote dIvoire & 0.39 & -0.38 & 11.49 & 0.36 & 0.38 & Portugal & 0.42 & -0.12 & 0.79 & 0.03 & 0.20 \\
\hline Denmark & -0.13 & -0.29 & -7.18 & -0.97 & -0.38 & Rwanda & 0.84 & -0.46 & 15.59 & 0.49 & 0.63 \\
\hline Dominican Rep & 0.72 & -0.19 & 8.32 & 0.26 & 0.43 & Saudi Arabia & 0.38 & 0.33 & 6.37 & 0.20 & 0.16 \\
\hline Ecuador & na & 0.32 & na & na & na & Senegal & 0.31 & -0.30 & 8.07 & 0.25 & 0.28 \\
\hline \begin{tabular}{|l} 
Egypt \\
EI Salvador
\end{tabular} & 0.27 & 0.03 & 2.31 & 0.08 & 0.14 & $\mid \begin{array}{l}\text { Seychelles } \\
\text { Serron }\end{array}$ & 0.66 & 0.20 & 10.15 & 0.32 & 0.35 \\
\hline \begin{tabular}{|l} 
EFinandodor \\
Findand
\end{tabular} & $\begin{array}{l}-0.160 \\
-0.80\end{array}$ & 0.122 & 3.05 3.051 & 0.10 & 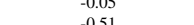 & Sierra Leone & 0.11 & -0.19 & 13.10 & 0.41 & 0.49 \\
\hline Finland & $\begin{array}{l}-0.80 \\
-0.85 \\
-15\end{array}$ & 0.33 & -2.361 & -0.31 & -0.51 & South Africa & 0.03 & -0.02 & 3.53 & 0.11 & 0.06 \\
\hline France & -0.45 & 0.11 & -0.62 & -0.08 & -0.24 & Spain & -0.25 & 0.45 & -0.34 & -0.04 & -0.20 \\
\hline Gabon & 0.78 & -0.28 & 17.82 & 0.55 & 0.59 & Sri Lanka & 0.09 & -0.11 & 1.58 & 0.05 & 0.08 \\
\hline Gambia & 0.14 & -0.32 & 8.67 & 0.27 & 0.23 & Sudan & -0.33 & -0.40 & -7.35 & -0.99 & -0.45 \\
\hline Germany & 0.47 & 0.40 & -2.40 & -0.32 & -0.02 & Swaziland & -0.20 & -0.17 & -0.53 & -0.07 & -0.08 \\
\hline Ghana & 0.25 & -0.12 & 16.11 & 0.50 & 0.33 & Sweden & nа & 0.38 & nа & па & nа \\
\hline Greece & 0.04 & 0.15 & 3.07 & 0.10 & 0.03 & Switzerland & -0.49 & 0.74 & 1.00 & 0.04 & -0.33 \\
\hline Guatemala & 0.54 & -0.19 & 6.13 & 0.19 & 0.33 & Syria & 0.59 & -0.37 & 11.20 & 0.35 & 0.45 \\
\hline Haiti & 0.25 & -0.29 & 8.95 & 0.28 & 0.27 & Tanzania & 0.38 & 0.08 & 3.39 & 0.11 & 0.18 \\
\hline Honduras & 0.17 & -0.06 & 4.62 & 0.15 & 0.14 & Thailand & na & 0.11 & $\begin{array}{c}\text { na } \\
7\end{array}$ & na & $\begin{array}{l}\text { na } \\
027\end{array}$ \\
\hline $\begin{array}{l}\text { India } \\
\text { Indonesia }\end{array}$ & $\begin{array}{l}0.43 \\
0.05\end{array}$ & $\begin{array}{l}-0.29 \\
-0.12\end{array}$ & $\begin{array}{l}1.04 \\
3.86\end{array}$ & $\begin{array}{l}0.04 \\
0.12\end{array}$ & $\begin{array}{l}0.25 \\
0.09\end{array}$ & \begin{tabular}{|l|l} 
Togo \\
Trinidad Tobaga
\end{tabular} & $\begin{array}{l}0.42 \\
0.67\end{array}$ & -0.03 & $\begin{array}{l}7.93 \\
885\end{array}$ & 0.25 & 0.27 \\
\hline Iranesia & $\begin{array}{l}0.05 \\
0.60\end{array}$ & $\begin{array}{l}-0.12 \\
-0.02 \\
-02\end{array}$ & $\begin{array}{l}3.86 \\
10.35\end{array}$ & $\begin{array}{l}0.122 \\
0.32\end{array}$ & $\begin{array}{l}0.099 \\
0.37\end{array}$ & \begin{tabular}{|} 
Trinidad Tobago \\
Tunisia
\end{tabular} & $\begin{array}{l}0.67 \\
0.30\end{array}$ & $\begin{array}{l}0.24 \\
-0.08\end{array}$ & $\begin{array}{l}8.85 \\
5.47\end{array}$ & $\begin{array}{l}0.28 \\
0.17\end{array}$ & $\begin{array}{l}.033 \\
0.21\end{array}$ \\
\hline Ireland & 0.07 & $\begin{array}{l}-0.09 \\
-0.092 \\
-0.02\end{array}$ & $\begin{array}{l}1.35 \\
1.67\end{array}$ & $\begin{array}{l}0.06 \\
0.06\end{array}$ & 0.07 & $\begin{array}{l}\text { Turkey } \\
\text { Turk }\end{array}$ & $\begin{array}{l}0.30 \\
-0.14\end{array}$ & -0.10 & & 0.17 & 0.03 \\
\hline Italy & -0.10 & 0.26 & 1.86 & 0.06 & -0.07 & Uganda & 0.39 & -0.41 & 24.47 & 0.76 & 0.54 \\
\hline Jamaica & -0.40 & 0.20 & 2.11 & 0.07 & -0.17 & & -0.67 & 0.11 & -1.61 & -0.21 & -0.37 \\
\hline Japan & 0.04 & 0.18 & 4.93 & 0.16 & 0.05 & United States & -0.37 & 0.00 & -0.86 & -0.11 & -0.19 \\
\hline Jordan & 0.15 & -0.38 & 2.17 & 0.07 & 0.16 & Uruguay & 0.58 & -0.46 & 10.98 & 0.34 & 0.46 \\
\hline Kenya & 0.28 & -0.29 & 7.00 & 0.22 & 0.26 & Venezuela, Rep. Bol. & 0.46 & -0.35 & 8.67 & 0.27 & 0.36 \\
\hline Korea & -0.32 & 0.09 & 3.00 & 0.10 & -0.11 & Vietnam & 0.13 & -0.05 & 3.33 & 0.11 & 0.11 \\
\hline Lao PDR & 0.06 & 0.01 & 1.31 & 0.05 & 0.04 & Yemen, Republic of & 0.59 & -0.12 & 8.59 & 0.27 & 0.37 \\
\hline \begin{tabular}{|l} 
Lebanon \\
Liberia
\end{tabular} & $\begin{array}{l}0.41 \\
0.00\end{array}$ & $\begin{array}{l}0.24 \\
0.00\end{array}$ & $\begin{array}{l}15.51 \\
32.42\end{array}$ & 0.48 & $\begin{array}{l}0.31 \\
0.40\end{array}$ & Zambia & 0.13 & 0.28 & -2.04 & -0.27 & -0.11 \\
\hline Liberia & 0.00 & 0.00 & 32.42 & 1.00 & 0.40 & Zimbabwe & 0.53 & -0.35 & 3.96 & 0.13 & 0.33 \\
\hline
\end{tabular}

Notes: The Index of Cyclicality of Fiscal Policy is a composite index that includes two measures of correlations of the cyclical components of fiscal policy instruments (Real Central Government Expenditure and the Inflation Tax) and real GDP (obtained using the HP Filter) and a measure of the amplitude of Real Central Government Expenditure Cycle as captured by the difference in growth of real central government expenditure in "Good" and "Bad" Times. The amplitude of the real central government expenditure cycle is transformed to a $(-1,1)$ indicator (comparable in values with the correlation indicatos 